\title{
1 Factors influencing the foliar elemental composition and stoichiometry in forest
}

2 trees in Spain

3

4.

5

6

7 Sardans, J. ${ }^{1,2^{*}}$, Alonso, R. ${ }^{3}$, Carnicer, J. ${ }^{1,2}$, Fernández-Martínez, M. ${ }^{1,2}$, Vivanco

8 M.G. ${ }^{3}$, Peñuelas, J. ${ }^{1,2}$.

9

$10{ }^{1}$ CSIC, Global Ecology Unit CREAF-CSIC-UAB, 08913 Cerdanyola del Vallès, Catalonia,

\section{Spain}

$12{ }^{2}$ CREAF, 08913 Cerdanyola del Vallès, Catalonia, Spain.

$13{ }^{3}$ Modelling and Ecotoxicology of Air Pollution, CIEMAT, Avda. Complutense 22 (edif. 70),

14 Madrid 28040, Spain.

$15{ }^{*}$ Corresponding author. Tel: 3493851 2934/Fax: 34938515141

16 E-mail: j.sardans@creaf.uab.es

17

18

19

20

21

This is the author's version of a work that was accepted for publication in Perspectives in plant ecology, evolution and systematics (Elsevier). Changes resulting from the publishing process, such as peer review, editing, corrections, structural formatting, and other quality control mechanisms may not be reflected in this document. Changes may have been made to this work since it was submitted for publication. A definitive version was subsequently published in Sardans, J. et al. "Factors influencing the foliar elemental composition and stoichiometry in forest trees in Spain" in Perspectives in plant ecology, evolution and systematics, vol. 18 issue 1 (Feb 2016), p. 52-69. DOl 10.1016/j.ppees.2016.01.001

25 


\section{ABSTRACT}

28 Concentrations of nutrient elements in organisms and in the abiotic environment are key

29 factors influencing ecosystem structure and function. We studied how concentrations and 30 stoichiometries of nitrogen $(\mathrm{N})$, phosphorus $(\mathrm{P})$ and potassium $(\mathrm{K})$ in leaves of forest trees

31 are related to phylogeny and to environmental factors (mean annual precipitation, mean 32 annual temperature, forest type, and nitrogen deposition). Using data for 4691 forest plots

33 from across Spain, we tested the following hypotheses: (i) that foliar stoichiometries of

34 forest trees are strongly influenced by phylogeny, (ii) that climate, as an important driver of

35 plant uptake and nutrient use efficiency, affects foliar stoichiometry, (iii) that long-term

36 loads of $\mathrm{N}$ influence $\mathrm{N}, \mathrm{P}$ and $\mathrm{K}$ concentrations and ratios in natural vegetation, and (iv)

37 that sympatric species are differentiated according to their foliar stoichiometry, thereby

38 reducing the intensity of resource competition.

39 Our analyses revealed that several factors contributed to interspecific variation in 40 elemental composition and stoichiometry. These included phylogeny, forest type, climate, $41 \mathrm{~N}$ deposition, and competitive neighborhood relationships (probably related to niche 42 segregation effect).

43 These findings support the notion that foliar elemental composition reflects 44 adaptation both to regional factors such as climate and to local factors such as competition 45 with co-occurring species.

46

47 Keywords: Calcium; C:K; C:N; C:P; ecological stoichiometry; growth rate hypothesis; mean 48 annual precipitation (MAP); mean annual temperature (MAT); Mediterranean ecosystems;

49 magnesium; N:P; N:K; P:K; potassium; sulfur; water stress

50

51

52 


\section{Introduction}

56 The leaf elemental composition and stoichiometry are important topics in forest research.

57 Foliar N:P ratios have been shown to correlate with the growth rate of plants (Elser et al.,

58 1996, 2000a and 2000b; Elser et al., 2010; Peñuelas et al., 2013a) and with the structure

59 and function of plant communities (Peñuelas et al., 2013a; Sardans et al., 2012a; Sterner

60 and Elser, 2002). Species with low foliar N:P ratios tend to grow rapidly and are more

61 competitive for soil resources than species with higher $N: P$ ratios, especially where

62 nutrient availability is high (Elser et al., 2001 and 2003; Willby et al., 2001). In the last

63 decade, there have been many studies of how foliar nutrient concentrations and

64 stoichiometries (mainly $\mathrm{N}: \mathrm{P}$ ) vary along environmental gradients, both at regional

65 (Santiago et al. 2004; Ordoñez et al., 2009; Sandel et al., 2010; Sardans et al., 2011) and

66 global (Reich and Oleksyn, 2004) scales. Whereas some of these have found significant

67 relationships between foliar N:P concentration ratios and climatic gradients (Kerkhoff et al.,

68 2005; Reich and Oleksyn, 2004; Yuan and Chen, 2009), others have produced how

69 contradictory results (Han et al., 2005; He et al. 2008; Lovelock et al., 2007;). Overall,

70 these studies suggest that climatic conditions do affect foliar elemental stoichiometry, but

71 that this relationship varies regionally and may be obscured by other factors such as the

72 distribution of plant groups, soil type, and plant growth strategy (Sardans et al., 2011,

73 2012a). Since climate influences plant water availability, temperature and light intensity

74 (Carte et al., 1997; Huxman et al., 2004; Voesenek and Pierik, 2008; Wang et al., 2012),

75 climatic variables such as mean annual temperature (MAT) and mean annual precipitation

76 (MAP) can be expected to determine, at least in part, the uptake of nutrients, and thus the

77 foliar elemental concentrations and stoichiometry. However, these will also be influenced

78 by other features of the ecosystem, including the dominant plant growth strategies (slow

79 versus fast growth, shade versus light tolerance, etc.), community composition and soil 
80 nutrient heterogeneity. As a consequence, we can expect to observe a spectrum of foliar

81 elemental composition and stoichiometry even at one site.

82 Most studies of plant stoichiometry have considered only $\mathrm{N}$ and P. However, 83 potassium $(\mathrm{K})$ is the most abundant nutrient in leaves after $\mathrm{N}$, and considerably more 84 abundant than P (Sardans et al., 2006b; Zheng and Shangguan, 2007). Together with N 85 and $\mathrm{P}, \mathrm{K}$ plays an important role in the physiology of terrestrial plants (Catmak, 2005). In 86 particular, it controls the water content of leaves by controlling stomatal function, cell 87 osmosis equilibrium and water fluxes (Babita et al., 2010; Fernández et al., 2006;

88 Khosravifar et al., 2008; Laus et al., 2011; Milla et al., 2005; Oddo et al., 2011). Including 89 potassium (K), therefore, should improve our understanding of the causes and 90 consequences of plant stoichiometric shifts among species, natural gradients and 91 competition conditions.

92 The concentration of $\mathrm{K}$ is especially significant in dry ecosystems because of its 93 role in physiological responses of the plant to varying water availability and shifts in foliar

$94 \mathrm{~N}: \mathrm{P}:$ Kratios are related to the change in response of plants to drought (Mairapetyan et al., 95 1999; Sardans and Peñuelas, 2007; Sardans et al., 2008b; Sardans and Peñuelas, 2008) 96 in the Mediterranean forests and shrub lands. Moreover, some forests of the main biomes 97 are K-limited (Nilsen and Abrahamsen, 2003; Olde Venterink et al., 2001; Tripler et al., 98 2004; Wright et al., 2011) and its concentrations and stoichiometrical relationships with $\mathrm{N}$ 99 and P are important to control water use efficiency (WUE) in dry environments (Egilla et 100 al., 2005; Graciano et al., 2005; Sardans et al., 2012a, 2012b; Welander and Ottosson, 101 2000). Some studies have found that a high concentration of $\mathrm{K}$ increases plant resistance 102 to drought (Egilla et al., 2005; Stone and Moreira, 1996), and that stoichiometric 103 relationships of $\mathrm{K}$ to $\mathrm{N}$ and $\mathrm{P}$ vary according to water availability (Peñuelas et al., 2013b; 104 Rivas-Ubach et al., 2012; Sardans and Peñuelas, 2007; Sardans et al., 2011). 
105 Other nutrients such as S, Mg or Ca may also limit growth in terrestrial plant communities

106 (Baribault et al., 2012; Hailes et al., 1997; Lapeins et al., 2013; Naples and Fisk, 2010),

107 albeit less commonly than N, P and K. Thus, in attempting to understand the factors that

108 influence foliar elemental chemistry, there is a need for studies that also consider many

109 more nutrients, including $\mathrm{Ca}, \mathrm{Mg}$ and $\mathrm{S}$.

110 Currently, apart from natural environmental circumstances such as climate

111 conditions, the use of fertlilizer and atmospheric deposition of $\mathrm{N}$ are likely to trigger shifts

112 in the N:P ratios of terrestrial plants (Peñuelas et al., 2012 and 2013a; Sardans et al., 2011

113 and 2012b; Veresoglou et al., 2014). Estimated loads of total annual atmospheric $\mathrm{N}$

114 deposition in Spain have approached $30 \mathrm{~kg} \mathrm{~N} \mathrm{ha}^{-1} \mathrm{yr}^{-1}$ (Avila and Rodà, 2012; Sanz et al.,

115 2002). These levels are generally lower than those recorded in central Europe, but

116 evidence from $\mathrm{N}$ concentrations of bryophytes in herbaria (Peñuelas and Filella, 2001) and

117 a growing abundance of nitrophilous species in Spanish terrestrial ecosystems (Ariño et al.

118 2011) points to continuing $\mathrm{N}$ enrichment. In several sites of Europe, forest defoliation and

119 dieback has been attributed to increasing $\mathrm{N}$ deposition (Jönsson et al., 2004; Pedersen

120 and Bille-Hansen, 1995; Thomas et al., 2002), which has been shown to affect leaching of

$121 \mathrm{~K}, \mathrm{Ca}, \mathrm{Mg}$ and $\mathrm{Na}$ from soil in temperate and boreal areas of Europe and North America

122 (Koptsik et al., 2007; Watmough et al., 2005). Meta-analysis of 107 independent studies of

123 forest nitrogen $(\mathrm{N})$ fertilization showed that the increase in $\mathrm{N}$ loads in temperate forest

124 ecosystems decreased the concentrations of base cations $\left(\mathrm{Ca}^{2+}, \mathrm{Mg}^{2+}, \mathrm{K}^{+}\right.$and $\left.\mathrm{Na}^{+}\right)$in soils

125 and increased their concentrations in soil water and stream runoff (Lucas et al., 2011).

126 Nutrient imbalance, particularly between $\mathrm{N}$ and other nutrients, is related to forest

127 defoliation and dieback in European forests (Lomský et al., 2012; Veresoglou et al., 2014)

128 and in other world areas (Wang et al., 2009). Under $\mathrm{N}$ deposition, plants are able to 129 increase their P and K uptake capacity (Rowe et al., 2008). P limitation favors higher plant 
130 phosphorus uptake through enhanced activity of soil phosphatases (Tresseder and

131 Vitousek, 2001) and root phosphatases (Gress et al., 2007; Phoenix et al., 2004) and by

132 changing symbiotic fungi (Lilleskov et al. 2002). These mechanisms seem quantitatively

133 insufficient to deliver enough phosphorus to alleviate P limitation (Vitousek et al., 2010),

134 thus $P$ becomes limiting (Turner et al. 2003; Bragazza et al. 2004) and P concentration

135 decreases (Bragazza et al., 2004; Braun et al., 2010; Jonard et al. 2012; Lévy et al.,

136 1999). Most studies show increase in $\mathrm{N}: \mathrm{P}$ and $\mathrm{N}: \mathrm{K}$ ratios under long-term $\mathrm{N}$ deposition in

137 several ecosystem pools such as plants (Britton et al., 2008; Lawniczak et al., 2009; Thelin

138 et al., 1998;) and soils (Olde Venterink et al., 2009) being N:K ratio related to changes in

139 the plant species-specific composition and diversity of terrestrial ecosystems (Roem and

140 Berendse, 2000). Thus, we would expect a wide effect of the gradients of $\mathrm{N}$ deposition on

141 foliar elemental composition and stoichiometry of Spanish forests.

142 An understanding of how foliar elemental composition vary among tree species and

143 along climatic gradients, and the different optima for elemental composition (not only $\mathrm{N}$

144 and P) among sympatric species, is relevant to forest management. These relationships

145 should be considered in assessing the most promising species for reforestation and in

146 managing existing forest areas. For example, some species may be more flexible than

147 others in their stoichiometry, and better able to adapt to increasing $\mathrm{N}$ loads through

148 deposition. An analysis of climatic and $\mathrm{N}$-deposition data at the regional level can improve

149 our understanding of the role of natural versus anthropogenic factors in determining plant

150 stoichiometry and its imbalance. Correction of nutrient imbalances is a key issue for the

151 success of afforestation, and survival and health of Spanish forests. Many of these are in

152 arid areas where nutrient supply has a crucial influence upon the water-use efficiency of

153 trees (Harvey and van den Driessche, 1999; Ripullone et al., 2004). 
155 use the main nutrients $\mathrm{N}, \mathrm{P}$ and $\mathrm{K}$ (and other essential nutrients such as $\mathrm{Ca}, \mathrm{Mg}$ and $\mathrm{S}$ ) in 156 differing proportions (Peñuelas et al., 2008 and 2010; Urbina et al., 2015), and therefore

157 occupy distinct regions in the multivariate space generated by the concentrations and

158 ratios of macro- and micronutrients in plant tissues. Since different plant structures and

159 metabolic processes have distinct and divergent requirements for each of the essential

160 nutrients, the species-specific biogeochemical niches should be the result of species

161 specialization to particular abiotic conditions. Moreover, these niches should reflect the

162 different species-specific strategies of growth and resources uptake and the differences in

163 soil space and time occupation. Ultimately, these differences contribute to reducing direct

164 competition among sympatric species (Peñuelas et al., 2008 and 2010; Urbina et al.,

165 2015). Despite the existence of biogeochemical niches, however, it is also known that

166 species exhibit varying degrees of stoichiometrical flexibility in response to environmental

167 changes (including ontogenical and seasonal-climate changes) and competitive situations,

168 probably under a tradeoff between flexibility and stability (homeostasis) capacity (Yu et al.,

169 2010). Yu et al. (2011) observed that species with higher stoichiometry flexibility have

170 higher concentrations of $\mathrm{N}$ and $\mathrm{P}$ and lower $\mathrm{N}: \mathrm{P}$ ratios.

171 We investigated the factors influencing the stoichiometry of trees using existing

172 data for Spanish forests. Our analysis was based upon four hypotheses. First, we

173 predicted that the elemental stoichiometries of different forest species should be strongly

174 determined genetically due to their long-term adaptation to specific abiotic and biotic

175 environments with optimized metabolic and physiological functions and morphological

176 structures that determine the specific use of various nutrients. Thus, distant taxonomic

177 groups should have an overall different elemental composition and stoichiometry. Second,

178 we hypothesized that an optimum stoichiometry for each climatic condition should be an 
179 important driver of plant uptake and nutrient use efficiency. These optima should reflect

180 trade-offs among several functions such as plant growth, resource storage and/or anti-

181 stress mechanisms for maximizing plant fitness in each of the particular climate situations.

182 Thus, different sets of species growing in different forest types under different climatic

183 conditions would tend to have different elemental composition and stoichiometry. Third, we

184 hypothesized that in several European zones N, P and $\mathrm{K}$ concentrations and ratios in

185 natural vegetation would reflect the long-term loads of $N$. Finally, we expected to find

186 differentiation in foliar composition stoichiometry among sympatric species, as predicted in

187 the biogeochemical niche hypothesis. These four hypotheses are not mutually

188 independent. In fact, a phylogenetic signal in elemental composition and stoichiometry

189 should be the result of long-term evolution under long-term climatic conditions and a

190 determined neighbourhood environment. Besides testing these four hypotheses, we also

191 tested the suitability of introducing in multivariate analyses other elements and ratios than

$192 \mathrm{~N}$ and $\mathrm{P}$ to test the biogeochemical niche hypothesis.

193

194

195

196

197

198

199

200

201

202 


\section{Methods}

204

205 Foliar data

206 The data on foliar analyses were assembled from several sources, including: (i) the

207 ecological forest inventory of Catalonia (Gracia et al., 2004), (ii) the third forest inventory of

208 Spain (IFN3, Villaescusa and Díaz, 1998; Villanueva, 2005), (iii) the TRY database (Kattge

209 et al., 2012); (iv) published papers available on the Web of Science till the year 2014; and

210 (v) the International Co-operative Programme on Assessment on Monitoring of Air

211 Pollution Effects on Forest (ICP Forest inventory) operated under the United Nations

212 Economic Commission for Europe (UNECE) and the Convention on Long-range

213 Transboundary Air Pollution (CLRTAP) (http://icp-forests.net/). All of these sources used

214 comparable methods to determine foliar elemental concentrations. In all cases $\mathrm{C}$ and $\mathrm{N}$

215 concentrations were determined by the Kjeldahl or Carlo Erba chromatographic analyses,

216 while the $\mathrm{P}$ and $\mathrm{K}$ concentrations were analyzed by atomic emission spectroscopy. The

$217 \mathrm{~N}: \mathrm{P}: \mathrm{K}$ concentration ratios, in leaves and needles, were calculated based on the mass. A

218 total of 5039 data values of 4294 sites contributed to the data for estimation of N:P ratios

219 and 3300 sites for foliar $\mathrm{N}: \mathrm{P}: \mathrm{K}$ ratios. To analyze all these data from different data sets we

220 used the annual average information of the data from ICP Forest data set. Additionally,

221 data for foliar concentrations of $\mathrm{N}, \mathrm{P}, \mathrm{S}, \mathrm{Mg}$ and $\mathrm{Ca}$ were analyzed from a subset of 948

222 analyses corresponding to 381 plots from the ICP sampled in different years within the

223 period 1990-2009. This forest inventory was randomly distributed across the Spanish

224 forests. All foliar samples were collected during the period of 1990-2009, from fully

225 expanded leaves. We used the $\mathrm{N}$ and $\mathrm{S}$ deposition (from EMEP) values estimated for 226 each site and for the same year of foliar sampling. 
228 geo-referenced data were processed using the MiraMon 6.0 (Pons 2009). The species and

229 forest types studied are mentioned in Table 1. The distribution of the plots and the

230 dominant forest ecotypes are shown in Figure 1.

231 We also used soil $\mathrm{N}$ concentration data (soil Kjeldalh-N) of 53 Spain plots from the

232 ICP Forest data base to analyze the effects of atmospheric $\mathrm{N}$ deposition on soil $\mathrm{N}$

233 concentrations in the organic soil layers.

234

235 Climatic data

236

237 For a comparative analysis, climatic data were obtained from two climatic models. For 238 each stand of forest, we used MAT and MAP data derived from the WorldClim database

239 (Hijmans et al., 2005) at a resolution of approximately $1 \mathrm{~km}^{2}$ at the equator and from the

240 Atlas climático digital de la Península Ibérica (Ninyerola et al., 2005) at a resolution of 4

241 ha. Both climatic models are based on interpolated values of climatic data provided by

242 weather stations located around the territory and adjusted to the observed topography.

243 MAP and MAT in both climatic models were calculated from long-term data (1950-1999 for

244 the Atlas climático database and 1950-2000 for the WorldClim database). The results from

245 the two models were almost identical with only minor improvements of one over the other

246 depending on the model. We present in the results section the model that explained the 247 most variance.

248

249 Atmospheric $N$ deposition

250 
251 Data for atmospheric $\mathrm{N}$ deposition were obtained from the European Monitoring and 252 Evaluation Programme (EMEP) of the Convention on Long-range Transboundary Air 253 Pollution (CLRTAP). The EMEP MSC-W chemical-transport model (Simpson et al., 2012)

254 has been developed to estimate regional atmospheric dispersion and deposition of 255 acidifying and eutrophicating compounds ( $\mathrm{N}$ and $\mathrm{S}$ ). This study used data for total 256 atmospheric $\mathrm{N}$ and $\mathrm{S}$ deposition estimated annually for the period 1990-2009 with EMEP 257 model rv3.8.1 over Europe using a grid size of $50 \mathrm{~km} \times 50 \mathrm{~km}$ (EMEP, 2011). We used the

$258 \mathrm{~N}$ and $\mathrm{S}$ deposition values estimated for each site and for the same year of foliar sampling.

259 Meteorological data were obtained from ECMWF-IFS Cycle36r1

260 (http://www.ecmwf.int/research/ifsdocs/); and the emissions during 2005 were derived from

261 the data submitted to the UNECE CLRTAP in 2011 (EMEP 2011).

262 We also used data for $\mathrm{N}$ deposition estimated with the CHIMERE model of regional 263 air quality. A detailed description of the model is available at the web link: 264 http://www.Imd.polytechnique.fr/chimere/ and in the article by Menut et al. (2013). The 265 simulations for the year 2005 were performed with the V200603par-rc1 version of 266 CHIMERE at a horizontal resolution of $0.2^{\circ}$ (approx. $20 \mathrm{~km}$ ) nested to a European-scale 267 simulation at a resolution of $0.5^{\circ}$, covering the Iberian Peninsula and the Balearic Islands. 268 Further description regarding the set-up of the model can be obtained from Vivanco et al. 269 (2009). The MM5 model was used to obtain meteorological fields (Reisner et al., 1998). 270 Emissions were derived from the annual totals in the EMEP database

271 (http://www.ceip.at/webdab-emission-database/emissions-as-used-in-emep-models). The

272 spatial distribution of emissions was determined, and the speciation of non-methane 273 volatile organic compounds was estimated as described by Vivanco et al. (2009). Oxidized 274 and reduced nitrogenous compounds and dry and wet depositions were considered. The 275 atmospheric $\mathrm{N}$ deposition values from CHIMERE are shown in Figure S1. 
277 Statistical analyses

278 We tested the following specific hypotheses: (i) the phylogenetic signal of different

279 foliar elemental concentrations and ratios individually, as well as the overall elemental 280 composition and stoichiometry, using multivariate analysis, (ii) the role of mean annual 281 precipitation (MAP), mean annual temperature (MAT), forest type (wet temperate 282 deciduous angiosperms -WDA-, Mediterranean deciduous forests -WDF-, Mediterranean 283 evergreen angiosperms -MEA-, wet temperate gymnosperms and alpine gymnosperms 284 WTG- and Mediterranean gymnosperms -MG- (iii) the role of N-deposition loads, and their 285 possible interactions on foliar N, P and K concentrations and stoichiometries, and (iv) the 286 differences in species-specific foliar elemental composition and stoichiometry among 287 sympatric species.

288 The phylogenetic fingerprinting analysis of the foliar elemental composition was done by 289 building a phylogenetic tree and obtaining the phylogenetic distances among species with 290 the Phylomatic and Phylocom (Webb and Donoghue, 2005; Webb et al., 2008). Briefly, the 291 Phylomatic uses a backbone plant mega-tree, which is primarily based on DNA data 292 composed from a variety of studies to assemble a phylogenetic tree for the species of 293 interest. Our phylogenetic hypothesis was based on the conservative mega-tree, where 294 unresolved nodes were included as soft polytomies (Webb and Donoghue, 2005). We 295 used the ape (Paradis et al., 2004) and picante (Kembel et al., 2010) libraries from the R 296 software (R Development Core Team, 2011) to check the phylogenetic signals among the 297 foliar elemental composition of the species studied; thereby determining the extent to 298 which the foliar $\mathrm{N}, \mathrm{P}, \mathrm{K}, \mathrm{Ca}$ and $\mathrm{Mg}$ concentrations, the N:P, N:K, P:K, N:Ca, P:Ca, K:Ca, 299 N:Mg, P:Mg, K:Mg and Ca:Mg ratios and the Principal Component Analysis (PCA) scores 300 had phylogenetic signals. We used the phylosignal function of the picante package that 
301 calculates a statistic of phylogenetic signal (Blomberg's $K$ ) and a $P$-value based on the

302 variance of phylogenetically independent contrasts, relative to tip shuffling randomization.

303 Blomberg's $K$ can range from 0 to 1 and indicates the strength of the phylogenetic signal in

304 the variable tested. A value close to 1 indicates that most of the variability in the data can

305 be explained by the phylogeny. We also correlated the phylogenetic distances between all

306 pairwise comparisons of the most representative 34 forest species with the corresponding

307 squared Mahalanobis distances from a discriminant function analysis (DFA) obtained with

308 foliar N, P, K, Ca, Mg and S concentrations and N:P, N:K and K:P ratios.

309 To test our second and third hypotheses, we analyzed the effects of climate and $\mathrm{N}$

310 deposition on foliar elemental composition in European forest. The data were analyzed

311 with general linear models (GLMs) using the foliar concentrations of the nutrients and the

$312 \mathrm{~N}: \mathrm{P}: \mathrm{K}$ concentration ratios, as dependent variables. Forest type (Mediterranean evergreen

313 angiosperms, Mediterranean gymnosperms, Mediterranean deciduous forests, wet

314 temperate and alpine gymnosperms and wet deciduous angiosperms) was used as a

315 categorical independent variable, and climatic variables (MAP and MAT) and N deposition

316 were used as continuous independent variables. The false discovery rate in the multiple

317 correlations to correct the alpha inflation was used (García, 2004). The direct linear

318 regressions of foliar concentrations of the nutrients and the $N: P: K$ concentration ratios

319 versus MAP, MAT and $\mathrm{N}$ deposition were conducted.

320 In the models to analyse the effects of MAP, MAT, and N deposition on needles,

321 degree of spatial autocorrelation in the residuals was assessed using Moran's I

322 correlograms and by plotting spatial maps of the distribution of residuals (following

323 Carnicer et al., 2011; Stefanescu et al., 2011). To assess the level of significance at each

324 distance class in the correlograms, 1000 permutations were computed using the resamp

325 argument in the correlog function (ncf package) of the R package. On obtaining significant 
326 autocorrelation in the residuals in ordinary least squares (OLS) models, simultaneous

327 autoregressive models (SAR) were applied spatially, to remove or at least decrease the

328 spatial autocorrelation in the residuals of the models. In these models, we used the forest

329 type as the categorical independent variable and MAP, MAT and the total atmospheric $\mathrm{N}$

330 deposition as the continuous independent variable. We used a factorial design, but in the

331 final models, we maintained the interactions only among the significant independent

332 variables. To detect the overall relationship (direct and indirect) of climate variables and $\mathrm{N}$

333 deposition on foliar $\mathrm{N}, \mathrm{P}$ and $\mathrm{N}: \mathrm{P}$ ratios, we performed Structural Equation Modelling

334 (SEM). We fitted the different models using the sem R package (Fox et al., 2013) and

335 achieved the minimum adequate model using the Akaike information criterion (AIC).

336 Standard errors and the significance level ( $P$-value) of the direct, indirect and total effects

337 were calculated using the bootstrap (with 1200 repetitions) technique (Davison et al., 338 1986; Mitchell-Olds, 1986).

339 To determine whether the nutrient concentrations and foliar $N: P: K$ concentration

340 ratios could discriminate among the forest types, we performed PCAs. We also conducted

341 a DFA in the subset of data from the ICP forest inventory of 381 plots for which we also

342 had the $\mathrm{S}, \mathrm{Mg}$ and $\mathrm{Ca}$ foliar concentration data, for a homogenous dataset randomly

343 distributed across the Spanish forested areas. Both ordination analyses are

344 complementary (Elliot et al., 2007; Johnson et al., 2003; Qadir et al., 2008; Stamova et al.,

345 2009). The DFA is a supervised statistical algorithm that establishes an optimal separation

346 between groups by maximizing the between-group variance and minimizing the within

347 group variances (Raamsdonk et al., 2001), whereas the PCA does not maximize between-

348 groups variation against within-group variance. For this subset of plots, we conducted the

349 PCA analysis with foliar N, P, K, S, Ca and Mg concentrations and N:P, N:K and P:K ratios 
350 as a proxy of biogeochemical niche of species, to determine the significance of any effect

351 of the climate and $\mathrm{N}$ deposition on the biogeochemical niche of species.

352 To test our fourth hypothesis, that the species growing in similar climatic conditions

353 should also present different elemental composition and stoichiometry within the group of

354 typical Mediterranean species (Mediterranean evergreen angiosperms, Mediterranean

355 gymnosperms and Mediterranean deciduous forests), we performed the PCA and the FDA

356 analyses. The analyses were done using the above variables to study the degree of

357 segregation of biogeochemical niches among species of the same climatic area or forest

358 type that frequently compete. The squared Mahalanobis distances from the discriminate

359 functional analysis among different species were used. We also used one-way analyses of

360 variance to detect any differences among the PC scores of the first and second

361 components for the three forest types. Regressions of the PC scores of the first and

362 second components with the climatic variables and $\mathrm{N}$ deposition levels were conducted for

363 detection of possible relationships of biogeochemical niche with climatic variables and $\mathrm{N}$

364 deposition. The variables were log-transformed for normalization of their distributions. We

365 also determined the species overlapping frequency (coincidence in the same community)

366 ( 0 = no overlapping, 1 = occasionally overlapping, 2 = moderate overlapping, $3=$ frequent

367 overlapping), in the set of the 13 most representative Mediterranean species, based in

368 Rivas-Martinez et al. (2001) De Bolos and Vigo (2001), CREAF, Catalonia cover map,

369 (2013) and Folk et al. (1984). Subsequently, the frequency of overlapping was correlated

370 with the scores of the first PC axes obtained by using foliar log-transformed foliar N, P, K,

$371 \mathrm{Ca}, \mathrm{Mg}$ and $\mathrm{S}$ concentrations and log-transformed foliar $\mathrm{N}: \mathrm{P}, \mathrm{N}: \mathrm{K}$ and $\mathrm{P}: \mathrm{K}$ ratios as

372 variables. The analyses were performed using StatView 5.0.1 (SAS Institute Inc., Berkeley

373 Ca, USA), Statistica 6.0 (StatSoft, Inc. Tule, Oklahoma, USA) and R (Core development 374 team, 2011). 


\section{Results}

376

377 Phylogenetic signal of foliar elemental composition and stoichiometry

378

379 Phylogenetic signals were observed for foliar N, K, Ca and S concentrations (Table 2). In

380 the case of $\mathrm{P}$ concentration, the phylogenetic signal was marginally significant, whereas it

381 was completely absent in case of foliar $\mathrm{Mg}$ concentration (Table 2). We found no

382 phylogenetic signal for foliar $\mathrm{N}: \mathrm{P}$ and $\mathrm{N}: \mathrm{K}$ ratios, and a marginally significant one for foliar

383 P:K ratio (Table 2). In a principal components analysis of foliar data for 37 tree species of

384 Spanish forests (N, P, K, Ca, Mg and S concentrations and log-transformed N:P, N:K and

385 P:K ratios), we found significant phylogenetic signals in the PC1, PC3 and PC4 axes and a

386 marginally significant signal in the $\mathrm{PC} 2$ axis $(\mathrm{P}=0.07)$ (Table 2). In addition, pairwise

387 differences between species in PC1, PC2 and PC3 scores were significantly correlated

388 with differences in phylogenetic distances (Figure 2). Foliar N:P ratios of gymnosperms

389 were significantly lower than those of angiosperms (Figure 3).

390

391 Climate and distribution of forest type

392

393 The two climatic models provided identical climatic data (data not shown). Figure S2

394 shows the distribution of MAT and MAP across Spain. Despite variation due to altitudinal

395 and continental effects, the data reveal a clear gradient of increasing MAP and decreasing

396 MAT from southeast to northwest, reflecting the transition from Mediterranean to

397 temperate Atlantic climates. This climatic gradient is associated with changes in tree

398 species, from typical Mediterranean species (Mediterranean evergreens angiosperms and 
399 Mediterranean gymnosperms) at the sites of higher MATs and lower MAPs to non-

400 Mediterranean species (wet temperate deciduous angiosperms and wet temperate and 401 alpine gymnosperms) at the sites of slightly lower MATs and higher MAPs, with 402 Mediterranean deciduous forests occupying intermediate sites (Figure 4).

403

404 Effects of climate, forest type and $\mathrm{N}$ deposition on foliar elemental composition

405

406 Data from general databases (ICP forest, TRY and Catalan and Spanish forest

407 inventories). MAP was positively correlated with the foliar $\mathrm{N}$ and $\mathrm{P}$ concentrations and

408 negatively with the $\mathrm{N}: \mathrm{P}$ ratios (Table 3), whereas MAT was negatively correlated with the

409 foliar $\mathrm{P}$ concentrations and positively with the $\mathrm{N}$ concentrations and the N:P ratios (Table

410 3). The deciduous forests generally had the highest foliar elemental concentrations, and

411 the Mediterranean gymnosperms had the lowest (Figure 5). Wet deciduous angiosperm

412 and Mediterranean gymnosperm forests had the highest foliar N:K ratios, while the wet

413 temperate and alpine gymnosperms had the highest foliar P:K ratios (Figure 3).

414 The geographical distributions of the available values of foliar $\mathrm{N}$ and $\mathrm{P}$

415 concentrations and $\mathrm{N}: \mathrm{P}$ ratios are shown in Figure S3. The log-transformed foliar N:P

416 ratios were negatively correlated with log-transformed $\mathrm{P}$ concentrations $(R=0.61$,

$417 P<0.0001)$, indicating a significant trend of decreasing foliar $\mathrm{N}: \mathrm{P}$ ratios with increasing $\mathrm{P}$

418 concentrations. When both foliar $\mathrm{N}$ and $\mathrm{P}$ concentrations increased, $\mathrm{P}$ tended to increase

419 more than $\mathrm{N}$, with the consequence that nutrient rich leaves tended to have lower $\mathrm{N}: \mathrm{P}$

420 ratios $(\mathrm{R}=0.61, P<0.0001)$ (Figure 6$)$. This effect was observed in all forest types. The PCA

421 analysis with log-transformed foliar $N, P$ and $K$ concentrations and $N: P, N: K$ and $P: K$ ratios

422 separated the five forest types along the first two axes (Figure S4). The angiosperm and

423 gymnosperm forests separated along PC1 (explaining 42.3\% of the total variance), with 
424 foliar $\mathrm{K}$ concentrations and foliar $\mathrm{N}: \mathrm{K}$ and $\mathrm{P}: \mathrm{K}$ ratios as the dominant factors, separated, 425 whereas Mediterranean forests from wet deciduous angiosperms separated along PC2 426 (explaining $31.6 \%$ of the total variance), with foliar $\mathrm{N}$ and $\mathrm{P}$ concentrations as the main 427 factors (Figure S4). The results also highlight the negative correlation between the foliar $428 \mathrm{~N}: \mathrm{P}$ ratios and $\mathrm{N}$ and $\mathrm{P}$ concentrations, with the slow-growing evergreens placed toward 429 lower foliar $\mathrm{N}$ and $\mathrm{P}$ concentrations and higher $\mathrm{N}: \mathrm{P}$ ratios (Figure S4).

430 In the general linear models (GLM) with climatic variables (MAT and MAP), forest 431 type, and $\mathrm{N}$ deposition as independent variables (Table $\mathrm{S} 1$ ), identical results (data not 432 shown) were obtained for different climatic and $\mathrm{N}$-deposition models. $\mathrm{N}$ deposition had a 433 positive interaction with MAP and MAT, increasing the foliar $\mathrm{N}$ concentration. Atmospheric $434 \mathrm{~N}$ deposition thus increased foliar $\mathrm{N}$ concentrations only when accompanied by high 435 values of MAP and/or MAT (Table S1). N deposition decreased the P concentrations, thus 436 significantly increasing foliar $\mathrm{N}: \mathrm{P}$ ratios (Table $\mathrm{S} 1$ ). The direct regression between log437 transformed foliar $\mathrm{N}$ concentration and log-transformed $\mathrm{N}$ deposition (without taking into 438 account the climate variables) was also significant (Figure 7). Atmospheric $\mathrm{N}$ deposition 439 was negatively correlated with foliar $\mathrm{P}$ and $\mathrm{K}$ concentrations and positively correlated with 440 foliar N:P ratio (Figure 7). Despite different species having distinct elemental profiles,

441 some species were relatively variable in their elemental composition (Figure S5). Among 442 the four most representative species, we observed that the foliar $\mathrm{P}$ concentration 443 decreased with MAP and MAT only in P. nigra (Figure S5). 444

445 Data from ICP forest database. To further study the possible effects of climate and $\mathrm{N}$ 446 deposition on foliar chemical composition, we used data for 381 forest plots from the ICP 447 Forest database. The results from the ordinary least square models and from SAR were 448 identical (Table S2). MAT and MAP, forest type and N deposition together explained 77\% 
449 of the variance in foliar $\mathrm{N}$ concentrations and 38,54 and $43 \%$ of the variability in $\mathrm{P}$ and $\mathrm{K}$ 450 concentrations and N:P ratios, respectively (Table S2). Autocorrelation and ordinary least 451 square models produced similar results (Table S2). Foliar $\mathrm{N}$ concentrations were 452 considerably higher at sites where high atmospheric $\mathrm{N}$ deposition coincided with elevated 453 MAP and, to a lesser extent, MAT. However, high atmospheric $\mathrm{N}$ deposition reduced the 454 foliar $\mathrm{P}$ concentrations, thereby significantly increasing the $\mathrm{N}: \mathrm{P}$ ratios (Table S2). 455 Consistent with these results, we observed that log-transformed total $\mathrm{N}$ deposition was 456 positively related with soil Kjeldahl-N across 53 plots from ICP database (Figure 8). The

457 PCA conducted with log-transformed foliar N, P, K, Ca, S and Mg concentrations and N:P, $458 \mathrm{~N}: \mathrm{K}$ and $\mathrm{P}: \mathrm{K}$ ratios distinguished deciduous, evergreen and gymnosperm species mainly 459 along PC1, which was essentially loaded with foliar N and S concentrations (Figure S6). 460 The score coefficients of PC1 were negatively correlated with MAP and N deposition 461 (Figure S6). Although these relationships were weak, they explained a part of the 462 variability in overall foliar elemental composition and stoichiometry, signifying that higher 463 foliar $\mathrm{N}$ concentrations are related to higher levels of MAP and $\mathrm{N}$ deposition. Most pairwise 464 species comparisons of the DFA detected statistical differences between the species' 465 elemental compositions (Table 4). The structural-path analysis model with climate (MAP 466 and MAT) and taxonomy (angiosperms versus gymnosperms) as exogenous variables and $467 \mathrm{~N}$ deposition, foliar $\mathrm{N}$ and $\mathrm{P}$ concentrations and foliar $\mathrm{N}: \mathrm{P}$ ratio as endogenous variables, 468 provided an overview of the relationships among these variables (Figure 9) and of the 469 total, direct and indirect effects (Figure 10). The model explained 47 and $88 \%$ of total 470 variance of foliar $\mathrm{N}$ concentration and $\mathrm{N}: \mathrm{P}$ ratio, respectively (Figure 9). Notably, there was 471 a considerable positive relationship between MAP and $\mathrm{N}$ deposition, a direct positive 472 relationship between $\mathrm{N}$ deposition and foliar $\mathrm{N}$ concentration and an indirect relationship of $473 \mathrm{~N}$ deposition and foliar $\mathrm{N}: \mathrm{P}$ ratio resulting from an indirect effect through foliar $\mathrm{N}$ 474 concentration (Figures 9 and 10). There was a negative relationship of MAT with foliar $\mathrm{N}$ 
475 concentration and even more with foliar $\mathrm{P}$ concentration, and hence a negative total 476 relationship of MAT with foliar N:P ratio (Figures 9 and 10). In contrast, there were positive 477 relationships between MAP and foliar $\mathrm{P}$ concentration and with foliar $\mathrm{N}$ concentration (the 478 latter reflecting in part an indirect effect of $\mathrm{N}$ deposition), and therefore also in a positive 479 relationship between MAP and foliar N:P ratio (Figure 10).

480

481 Mediterranean species and their differences in elemental composition and stoichiometry 482

483 In the PCA, conducted with the same variables but only for a subset of typical 484 Mediterranean forests $(n=306)$, most species tended to separate throughout the space 485 formed by the first two PCA axes (Figure 11), showing that these species of the same 486 Mediterranean group, which frequently coexisted and competed, tended to have different 487 foliar elemental compositions. Moreover, PC2 correlated significantly with N deposition 488 (higher $\mathrm{N}$ deposition related to higher foliar $\mathrm{N}$ concentrations and $\mathrm{N}: \mathrm{P}$ ratios), although the 489 relationship only explained $5 \%$ of the variation (Figure 11). Pairwise species differences in 490 the PC1 scores increased with increasing overlapping presence of the other species in the 491 same community (Figure 12). In the corresponding DFA analysis, the 13 dominant 492 Mediterranean species of Spain each had a distinctive profile in terms of foliar elemental 493 composition and stoichiometry (Table 5). 
499 Discussion

500

501 Phylogeny, leaf elemental composition and stoichiometry

502

503 The results indicate that leaf elemental composition exhibits a strong phylogenetic signal

504 for five of the six elements analyzed and in terms of stoichiometry. Thus, our first

505 hypothesis - that the foliar elemental composition is related with long-term evolution and

506 natural selection processes - is supported.

507 Some of these phylogenetic differences may be of great ecological relevance. For

508 example, in all forest types lower foliar $\mathrm{N}: \mathrm{P}$ ratios tend to be associated with higher $\mathrm{N}$ and

$509 \mathrm{P}$ concentrations, suggesting that $\mathrm{N}: \mathrm{P}$ ratios tend to decrease in nutrient-rich

510 environments. Such relationships are mostly observed in angiosperms and not in

511 gymnosperms, which mainly had lower foliar $N$ and $P$ concentrations and lower $N: P$ ratios.

512 The differences between angiosperms and gymnosperms explain a significant part of the

513 variation in foliar elemental composition and stoichiometry among species, and strongly

514 suggest that evolutionary processes have played an important role. Alternatively and/or

515 complementarily to this hypothesis, at least in these Spanish forests, where gymnosperms

516 are usually the initial successional species, the pioneering success of gymnosperms could

517 also account for the low foliar $\mathrm{N}: \mathrm{P}$ ratios due to the higher proportional availability of $\mathrm{P}$

518 relative to $\mathrm{N}$ in the initial phases of succession, for example, after a fire event. The latter

519 hypothesis seems reasonable for our dataset, because the most abundant gymnosperm

520 forests, such as those dominated by Pinus halepensis, $P$. pinaster, $P$. nigra, and $P$.

521 sylvestris usually constitute the early forest stage, and are most frequently replaced by

522 angiosperms, such as Quercus ilex, Q. suber, Q. humilis, Q. petrea, Q. pyrenaica, and

523 Fagus sylvatica in more advanced successional stages. Further, our results suggest that 
524 coniferous trees might grow better in soils with lower $\mathrm{N}: \mathrm{P}$ ratios because their optimum

525 mass-based N:P ratio is under 14, which could indicate high $\mathrm{P}$ requirements (Bott et al.,

526 2008; Güsewell and Bollens, 2003). In contrast, angiosperms with mass-based N:P ratios

527 above 15-16, which enable the trees to grow better in soils with high $\mathrm{N}: \mathrm{P}$ ratios, are

528 frequently associated with the older soils of more advanced successional stages.

529

530 Relationships of climate and forest type with foliar $N$ and $P$ concentrations and $N: P$ ratios

532 The present work supports previous studies carried out to analyze the effects of climate on

533 foliar $\mathrm{N}$ and $\mathrm{P}$ concentrations and $\mathrm{N}: \mathrm{P}$ ratios. Optimum climatic conditions for growth often

534 coincide with high foliar $\mathrm{N}$ and $\mathrm{P}$ concentrations and with low N:P ratios (Kerkhoff et al.,

535 2005; Reich and Oleksyn, 2004; Sardans and Peñuelas, 2013; Yuan and Chen, 2009).

536 The positive effect of water availability on mineralization and nutrient availability can be

537 especially important in naturally dry environments, such as the Mediterranean ecosystems

538 (Jarvis et al. 2007; Sardans and Peñuelas 2005 and 2010; Sardans et al. 2008c). We have

539 observed that MAP, the climatic factor that most frequently limits growth in the forests of

540 Spain, is positively correlated with higher foliar N, P and K concentrations. On the other

541 hand, relationships with MAT are weaker and opposite to those of MAP. The multifactorial

542 GLM models indicated that the positive relationship between MAP and foliar N, P and K

543 concentrations occurred particularly where high MAPs coincided with high MATs and N

544 depositions. Further, these relationships were partially due to the effects of climate on the

545 distribution of different forest types, with deciduous forests occupying the wettest

546 environments and having the highest foliar $\mathrm{N}, \mathrm{P}$ and $\mathrm{K}$ concentrations. Deciduous

547 angiosperms in Spain are frequently associated with optimum climatic conditions (as

548 shown in Figure 2). It has been noticed that in the PCA analysis, foliar $\mathrm{K}$ concentration is 
549 also higher for the forests occupying the wettest environments and the Mediterranean

550 evergreen angiosperms. This indicates the dual importance of $\mathrm{K}$ being the main element

551 loading in the PC1, discriminating angiosperms from gymnosperms and also separating

552 forests occupying the wettest environments from other forests. The higher growth

553 capacities of wet deciduous angiosperm forests in Catalonia had already been associated

554 with higher water availability and foliar N, P and K concentrations (Sardans and Peñuelas,

555 2013). The use of precipitation and temperature distribution during the growth period

556 instead of MAP and MAT would very likely yield closer relationships between climate and

557 elemental composition, but these data were not available. Extreme climatic events could

558 also be even more strongly related to plant elemental composition (Kreyling et al., 2010;

559 Urbina et al. 2015). Moreover, although each species tends to have a specific foliar

560 elemental composition, we detected certain degree of flexibility in species-specific

561 elemental composition along the climate gradients. Thus, another significant part of the

562 variance of the foliar elemental composition and stoichiometry among different species

563 and also among individuals of the same species can be explained by the prevailing

564 climatic conditions, as our second hypothesis claimed.

565

$566 N$ deposition and forest stoichiometry

567

568 The large gradients of $\mathrm{N}$ deposition across the forested areas of Spain allowed us to

569 detect the influence of deposition on forest elemental composition. All analyses indicated

570 that $\mathrm{N}$ deposition had already affected some Spanish forests, particularly, due to an

571 increase in the foliar $\mathrm{N}$ concentration and $\mathrm{N}: \mathrm{P}$ ratios. Atmospheric $\mathrm{N}$ deposition increased

572 foliar $\mathrm{N}$ concentrations, particularly in areas where high levels of $\mathrm{N}$ deposition coincided

573 with high levels of MAT and, mainly, of MAP. This effect suggests that, under climatic 
574 conditions favourable for growth, high $\mathrm{N}$ loadings tend to be retained by forests. If this

575 trend continues, however, the species with high foliar $\mathrm{N}: \mathrm{P}$ ratios could be favoured under

576 high levels of $\mathrm{N}$ deposition. The results also suggest that the increase in P-limitation under

577 high levels of $\mathrm{N}$ deposition could benefit angiosperms over gymnosperms in Spanish

578 forests, especially in areas where the climate favours rapid tree growth. The data

579 coincided with the decrease of gymnosperms forest cover in favor of angiosperms forest

580 cover in Spanish forests (Carnicer et al., 2013; Coll et al., 2011).

$581 \quad$ Several previous studies have detected increases in foliar $\mathrm{N}$ concentrations in

582 terrestrial plants in Europe owing to N deposition (Dukesnay et al., 2000; García-Palacios

583 et al., 2012; Kang et al., 2011; Solberg et al., 2002) and have also detected increases in

584 N:P ratios (Dukesnay et al., 2000; Kang et al., 2011), together with decreases in foliar P

585 concentration related to enhancement of P defficiences (de Vries et al., 1995; Dukesnay et

586 al., 2000; Erisman et al., 1998; Jonard et al., 2015; Solberg et al., 2002). Our results,

587 however, show that foliar $\mathrm{P}$ concentrations can decrease as a consequence of $\mathrm{N}$

588 deposition and that a general change in foliar elemental composition involving other

589 elements such as $\mathrm{K}$ could also occur on a global scale due to uninterrupted $\mathrm{N}$ loadings

590 from $\mathrm{N}$ deposition. The moderate direct effects of $\mathrm{N}$ deposition on foliar $\mathrm{N}$ concentrations

591 that we observed were consistent with studies performed in undisturbed mountainous

592 areas of North Spain (Amores et al., 2006). Long-term studies in Northeast Spain, among

593 the regions with highest levels of atmospheric $\mathrm{N}$ deposition, performed in the undisturbed

594 catchments showed that these ecosystems are still far from $\mathrm{N}$ saturation, because most of

595 the deposited $\mathrm{N}$ is retained within the ecosystem, and only small increase in $\mathrm{NO}_{3}{ }^{-}$

596 concentrations could be detected in stream water (Àvila and Rodá, 2012). Indeed, in a

597 previous study, we have found a positive relation between $\mathrm{N}$ deposition and soil organic- $\mathrm{N}$

598 for 53 forest plots, suggesting that those soils had a considerable capacity to retain $\mathrm{N}$. 
599 Increase in $\mathrm{N}$ deposition can increase the immobilization of $\mathrm{P}$ in the soils of forested areas

600 through the high uptake of P by the soil food web (Piatek et al., 2009), and several studies

601 have concluded that high and continuous $\mathrm{N}$ loadings increase $\mathrm{P}$ limitation (Boxman et al., 602 1994; Gradowski and Thomas, 2008; Huang et al., 2012 Phoenix et al., 2003). However, 603 when the $\mathrm{N}$ loadings increase, plants and soil organisms' enhance the synthesis of their 604 phosphatases to increase P uptake. Such mechanisms do not prevent a lasting increase in $605 \mathrm{~N}: \mathrm{P}$ ratios (Peñuelas et al., 2013a). Regarding our third hypothesis, although there are no 606 adequate data of temporal series of $\mathrm{N}$ deposition versus foliar composition, there is some 607 evidence that current high $\mathrm{N}$ deposition loads in certain areas of Spain may lead to 608 changes in foliar elemental composition, especially in the more productive areas.

610 The case of sympatric species

611

612 Different tree species growing in the same Mediterranean climate tend to have contrasting 613 foliar elemental profiles. Such contrasts were especially clear among species that 614 habitually coexist, such as $Q$. ilex, $P$. halepensis and Juniperus oxycedrus, or $Q$. suber, $P$. 615 pinea and $P$. pinaster, and tended to be less apparent or not significant among species 616 that are rarely found together, such as $P$. pinaster and $P$. nigra (CREAF, Catalonia cover 617 map, 2013). Thus, these results support previous studies that found a tendency of 618 coexisting plant species to have different elemental compositions (Peñuelas et al., 2008, 619 2010). This dimension of biogeochemical niche would coincide with the complementary 620 niche hypothesis (Hector et al., 1999). Neighbouring species may exhibit different 621 interactions with the environment due to their species-specific functioning and morphology. 622 Indeed, coexisting plant species might even differentiate their stoichiometries to avoid 623 direct competition by enhancing diversity in their uses of nutrients or could also change 
624 their stoichiometries by shifting some functions to better cope with different competitive

625 circumstances. These strategies should help reduce the negative impacts of interspecific

626 competition and also improve the productive capacity of the global community, as

627 expected by the complementary niche hypothesis (Hector et al., 1999).

628

629 The combined effects of climate, forest type and competition on overall foliar composition:

630 testing the biogeochemical niche hypothesis (BNH)

632 The biogeochemical niche of each species, understood as the region occupied in the

633 multivariate space generated by the content of macro- and micronutrients in plant tissues

634 (Peñuelas et al., 2008, 2010), was significantly different among the forest species of

635 different climatic areas (Mediterranean forests relative to wet temperate and alpine forests)

636 and between different taxonomic groups (angiosperms and gymnosperms). Moreover, the

637 results showed that sets of plant species growing under the same climatic conditions that

638 frequently coexist tend to diverge in their elemental composition. The results thus showed

639 that apart from the shift of foliar composition in coexisting species, taxonomy, current

640 climatic conditions, and human driven impacts such as atmospheric $\mathrm{N}$ deposition also

641 determined a significant and important part of the variability in foliar elemental composition

642 and stoichiometry. In this context, we have observed that foliar compositions and

643 stoichiometries were more similar among the Mediterranean evergreen angiosperms than

644 other angiosperms growing under different climatic conditions. For example, the evergreen

645 Q. suber, typical of acidic soils, has a foliar elemental composition more similar to that of

646 the evergreen $Q$. ilex, which frequently prefers neutral and basic soils, than to that of other

647 Quercus species growing in acidic soils but in wetter climates, such as $Q$. pyrenaica, $Q$.

648 petraea or $Q$. robur (Figure 6). Similarly, gymnosperms such as $P$. pinaster growing in 
649 acidic soils have foliar elemental compositions more similar to those of other 650 gymnosperms such as $P$. halepensis growing in basic soils than to those of angiosperms 651 growing in acidic soils but in the same climate, such as $Q$. suber, or in a different climate, 652 such as $Q$. robur (Figures 6 and 8). Species thus tend to occupy the climate areas where 653 they are better adapted and this explains a part of their foliar composition. The overall 654 results were thus consistent with the $\mathrm{BNH}$.

655 Climate is not the only driver of the evolutionary processes; factors such as 656 interspecific competition and soil nutrient status are also important. The results were thus 657 consistent with the idea that each individual species, being the original product of a 658 singular evolutionary history under specific abiotic (climate, soil type, etc.) and biotic 659 (trophic relationships, neighbor competitors, etc.) conditions, tends to have it own 660 elemental profile and stoichiometry. Nonetheless, as observed here, species may exhibit 661 flexibility in stoichiometry in response to environmental changes (including ontogenical and 662 seasonal changes) and competitive conditions (Dybzynski et al., 2013). There is a tradeoff 663 between adaptation capacity (flexibility by short term responses) and stability (some 664 degree of homeostasis obtained under species-specific evolutionary history) (Yu et al., 665 2010). These two components can also differ for the evolutionary process of a particular 666 species. Moreover, as predicted by the $\mathrm{BNH}$, the concentrations of elements such as $\mathrm{K}$ 667 and $\mathrm{Ca}$ had differences similar to those of $\mathrm{P}$ and $\mathrm{N}$ among species of different climatic 668 areas, forest types or taxonomic groups and among species growing within a climatic area 669 and forest type. These other elements thus warrant more attention in ecological 670 stoichiometric studies in terrestrial plant communities.

672 Foliar composition and forest management 
674 A knowledge of the elemental profiles (not only $\mathrm{N}$ and $\mathrm{P}$ ) of sympatric species at a regional 675 scale could be useful in deciding which species or species combinations to plant at 676 particular sites, both for forest conservation and wood production. The sites with high $\mathrm{N}$ 677 deposition that coincides with more productive climatic conditions tend to present greater 678 nutrient imbalances. In this regard the fact that $\mathrm{N}$ deposition generates larger foliar $\mathrm{P}$ 679 decreases in gymnosperms than in angiosperms could also be underlying in a higher 680 decrease of gymnosperm forest cover in favor of angiosperm forest cover observed in 681 Spain forests (Carnicer et al., 2013; Coll et al., 2013). Coll et al. (2013) correlated this 682 change in coverage of the two clades to climate change effects, but the results of this 683 study suggest that the impacts of $\mathrm{N}$ deposition can also contribute to this shift. This factor 684 should be considered in new reforestation politics. The forest species with natural foliar 685 composition with high $\mathrm{N}$ and low concentrations of other elements would be most 686 adequate in these conditions, not only due to their better survival but also because they 687 might improve the system imbalance. As commented previously, successful afforestation 688 and maintaining healthy forests may depend upon correcting nutrient imbalances, 689 especially in more arid regions where water-use efficiency is critical. Thus, the information 690 of the natural elemental composition, including the concentration of other elements than $\mathrm{N}$ 691 and $P$ involved in water use, is necessary for afforestation programs, including the 692 possibility for soil amendments. Forest management has been very focused on $\mathrm{N}$ and $\mathrm{P}$, 693 and yet this study shows that other elements such as $\mathrm{K}$ or Ca can have different optima 694 among species in a range even greater than that of $\mathrm{N}$ and $\mathrm{P}$. This fact should be taken into 695 consideration in forest management. This study provides data on nutrient availability in 696 forest under different climatic regimes that will be useful when taking decisions for the 697 management of Spanish forests.

698 


\section{Conclusions and final remarks}

700 1. Differences among species of the foliar concentrations of five of the six elements

701 analyzed and also overall foliar composition and stoichiometry were related to the

702 corresponding phylogenetic distances among species. When comparing phylogenetic

703 groups we further confirmed this link. For example, gymnosperms had lower foliar $\mathrm{N}$ and $\mathrm{P}$

704 concentrations and N:P ratios than did angiosperms. Our results showed that phylogenetic

705 distances explain a significant part of overall species-specific elemental foliar composition

706 and stoichiometry differences.

707 2. Climate and forest type accounted for a significant part of the variance in foliar $\mathrm{N}$ and $\mathrm{P}$

708 concentrations and N:P ratios among different forest tree species, and explained a

709 significant part of overall species-specific elemental foliar composition and stoichiometry

710 differences. Foliar $\mathrm{N}$ and $\mathrm{P}$ concentrations generally increased as $\mathrm{N}: \mathrm{P}$ ratios decreased,

711 and sites with better climatic conditions for plant production had lower N:P ratios. All these

712 results showed that each climate condition is an important driver fot plant nutrient uptake

713 and use.

714 3. $\mathrm{N}$ deposition tended to increase foliar $\mathrm{N}$ concentrations and $\mathrm{N}: \mathrm{P}$ ratios, and to decrease

715 foliar P concentrations, particularly when coinciding with high MAPs and MATs. Thus, N

716 deposition had a weak but significant effect explaining part of the overall variation in

717 elemental foliar composition and stoichiometry.

718 4. Sympatric species have different elemental compositions. Species of the same Genus

719 tend to be more different in elemental composition when they are sympatric than allopatric.

720 Thus, the data are consistent with the niche segregation hypothesis: that coexisting plant

721 species avoid direct competition by having contrasting stoichiometries.

722 5. The overall results supported the hypothesis that foliar elemental composition and 723 stoichiometry (here represented by $\mathrm{N}, \mathrm{P}, \mathrm{K}, \mathrm{Ca}, \mathrm{Mg}$ and $\mathrm{S}$ ) are species-specific supporting 
724 the biogeochemical niche hypothesis. This study showed that the species-specific foliar

725 elemental composition and stoichiometry are, to a large extent, explained by taxonomical

726 differences, current climatic conditions, and competitive neighborhood relationships

727 (probably related to niche segregation effect). Human-driven $\mathrm{N}$ deposition can also exert

728 some influence explaining a minor but significant part of overall leaf composition and

729 stoichiometry variability among the studied set of forest species in Spain.

730

731 Acknowledgements

732

733 This research was supported by the European Research Council Synergy grant ERC-

734 2013-SyG-610028 IMBALANCE-P, the European FP7-ENV ECLAIRE project, the Spanish

735 Government projects CGL2013-48074-P and Consolider-Ingenio Montes CSD2008-00040

736 and the Catalan Government project SGR 2014- 274. MFM was funded by a Catalan

737 Government FI grant. We are especially grateful to the scientists and technicians that

738 developed the Catalan Forest Inventory (Gracia et al., 2004), to Isaura Rábago from

739 CIEMAT for helping in preparing the $\mathrm{N}$-deposition data and to Anna Carlin Benedictow of

740 the Norwegian Meteorological Institute and Gerardo Sánchez-Peña for providing the

741 EMEP and ICP-Forest data.

742

743

744

745

746

747

748

749

750 


\section{References}

752 Amores, G., Bermejo, R., Elustondo, D., Lasheras, E., Santamaria, J.M., 2006. Nutritional status of Northern Spain beech forests. Water Air Soil Pollut. 177, 227-238.

754 Ariño, A.H., Gimeno, B.S., Pérez de Zabalza, A., Ibáñez, R., Ederra, A., Santamaría, J.M.,

755

756

757

758

759

760

761

762

763

764

765

766

767 2011. Influence of nitrogen deposition on plant biodiversity at Natura 2000 sites in Spain. In: Nitrogen Deposition and Natura 2000. Science \& practice in determining environmental impacts. pp. 140-146.

Àvila, A., Rodà, F., 2012. Changes in atmospheric deposition and streamwater chemistry over 25 years in undisturbed catchments in a Mediterranean mountain environment. Sci. Total Environ. 434, 18-27.

Babita, M., Maheswari, M., Rao, L.M., Shanker, A.K., Rao, D.G., 2010. Osmotic adjustment, drought tolerance and yield in castor (Ricinus communis L.) hybrids. Environ. Exp. Bot. 69, 243-249.

Baribault, T.W., Kobe, R.K., Finley, A.O., 2012. Tropical tree growth is correlated with soil phosphorus, potassium, and calcium, though not for legumes. Ecol. Monogr. 82, 189-203.

Blomberg, S.P., Garland, T.Jr, Ives, A.R., 2003. Testing for phylogenetic signal in comparative data: behavioral traits are more labile. Evolution 57, 717-745.

Bott, T., Meyer, G.A., Young, E.B., 2008. Nutrient limitation and morphological plasticity of the carnivorous pitcher plant Sarracenia purpurea in contrasting wetland environments. New Phytol. 180, 631-641.

Boxman, A.W., Cobben, P.L.W., Roelofs, J.G.M., 1994. Does (K+Mg+Ca+P) fertilization lead to recovery of tree health in a nitrogen stressed Quercus-rubra $L$ stand. Environ. Pollut. 85, 297-303.

Bragazza, L., Tahvanainen, T., Kutnar, L., Rydin, H., Limpens, J., Hajek, M., Grosvernier, P., Hajek, T., Hajkova, P., Hansen, I, et al., 2004. Nutritional constrains in ombrotrophic Sphagnum plants under increasing atmospheric nitrogen deposition in Europe. New Phytol. 163, 609-616.

Braun, S., Thomas, V.F.D., Quiring, R., Fluckiger, W., 2010. Does nitrogen deposition increase forest production? Ther role of phosphorus. Environ. Pollut. 158, 20432052. 
782 Britton, A.J., Helliwell, R.C., Fisher, J.M., Gibbs, S., 2008. Interactive effects of nitrogen 783 deposition and fire on plant and soil chemistry in an alpine heathland. Environ. 784 Pollut. 156, 409-416.

785 Bussotti, F., Borghini, F., Celesti, C., Leonzio, C., Bruschi, P., 2000. Leaf morphology and 786 macronutrients in broadleaved trees in central Italy. Trees, 14, 361-368.

787 Cakmak I 2005 The role of potassium in alleviating detrimental effects of abiotic stresses 788 in plants. J. Plant Nutrit. Soil Sci. 168, 521-530.

789 Carnicer, J., Coll, M., Ninyerola, M., Pons, X., Sánchez, G., Peñuelas, J., 2011. 790 Widespread crown condition decline, food web disruption, and amplified tree 791 mortality with increased climate change-type drought. Proc. Natl. Aca. Sci U.S.A. $792 \quad 108,1474-1478$.

793 Carnicer, J., Barbeta, A., Sperlich, D., Coll, M., Peñuelas, J., 2013. Contrasting trait 794 syndromes in angiosperms and conifers are associated with different responses of 795 tree growth to temperature on a large scale. Front. Plant Sci. doi: $796 \quad 10.3389 /$ fpls.2013.00409.

797 Carter, EB, Theodorou, MK, Morris, P, 1997 Responses of Lotus corniculatus to 798 environmental change. 1. Effects of elevated $\mathrm{CO}_{2}$ temperature and drought on 799 growth and plant development. New Phytol. 136, 245-253.

800 Coll, M., Peñuelas, J., Ninyerola, M., Pons, X., Carnicer, J., 2013. Multivariate effect 801 gradients driving forest demographic responses in the Iberian Peninsula. For. Ecol. 802 Manag. 303, 195-209.

803 CREAF, 2013 Land Cover Map of Catalonia (MCSC) [online]. Available from: 804 http://www.creaf.uab.cat/mcsc/usa/index.htm.

805 Davison, A. C., Hinkley, D. V., Schechtman, E., 1986. Efficient Bootstrap Simulation. 806 Biometrika, 73, 555-566.

807 De Bolos, O., Vigo, J., 2001. Flora dels Països Catalans (I-IV). Barcino (Ed), Barcelona.

808 De Miguel, J., Sánchez, A., Auñón, F.J., García, J.M., 2011. Forest and forestry in Spain.

$809 \quad$ Edited by: Instituto Nacional de Investigación y Tecnología Agraria y Alimentaria

810 De Vries, W., Leeters, E.E.J.M., Hendriks, C.M.A., 1995. Effects of acid deposition on 811 Dutch forest Ecosystems. Water Air Soil Pollut. 85, 1063-1068. 
812 Duquesnay, A., Dupouey, J.L., Clement, A., Ulrich, E., 2000. Spatial and temporal

813 variability of foliar mineral concentration in beech (Fagus sylvatica) stands in

814 northeastern France. Tree Physiol. 20, 13-22.

815 Dybzinski, R., Farrior, C.E., Ollinger, S., Pacala, S.W., 2013. Interespecific versus 816 intraspecific patterns in leaf nitrogen of forest tree across nitrogen availability 817 gradient. New Phytol. 200, 112-121.

818 Egilla, J.N., Davies, F.T., Boutton, T.W., 2005. Drought stress influences leaf water 819 content, photosynthesis, and water-use efficiency of Hibiscus rosa-sinensis at three 820 potassium concentrations. Photosynthetica 43, 135-140.

821 Elliot, G.N., Geoffrey, N., Worgan, H., Broadhurst, D., Draper, J., Scullion, J., 2007. Soil 822 differentiation using fingerprinting Fourier transform infrared spectroscopy, 823 chemometrics and genetic algorithm-based feature selection. Soil Biol. Biochem. 39, 824 2888-2896.

825 Elser, J.J., Dobberfuhl, D.R., MacKay, N.A., Schampel, J.H., 1996. Organism size, life 826 history, and N: P stoichiometry. Bioscience 46, 674-684.

827 Elser, J.J., Fagan, W.F., Denno, R.F., Dobberfuhl, D.R., Folarin, A., Huberty, A., Interlandi, 828 S., Kilham, S.S., McCauley E., Schulz, K.L., Siemann, E.H., Sterner, R.W., 2000a. 829 Nutritional constrains in terrestrial and freshwater food webs. Nature 408, 578-580.

830 Elser, J.J., Sterner, R.W., Galford, A.E., Chrzanowski, T.H., Findlay, D.L., Mills, K.H., 831 Paterson, M.J., Stainton, M.P., Schindler, D.W., 2000b. Pelagic C: N: P 832 stoichiometry in a eutrophied lake: responses to a whole-lake food-web 833 manipulation. Ecosystems 3, 293-307.

834 Elser, J.J., Hayakawa, K., Urabe, J., 2001. Nutrient limitation reduces food quality for 835 zooplankton: Daphnia response to seston phosphorus enrichment. Ecology 82, 898836903.

837 Elser, J.J., Acharya, K, Kyle, M, Cotner, J., Makino, W., Markow, T., Watts, T., Hobbie, S., 838 Fagan, W., Schade J., 2003. Growth rate-stoichiometry couplings in diverse biota. $839 \quad$ Ecol. Lett. 6, 936-943.

840 Elser, J.J., Fagan, W.F., Kerkhoff, A.J., Swenson, N.G., Enquist, B.J., 2010. Biological 841 stoichiometry of plant production: metabolism, scaling and ecological response to 842 global change. New Phytol. 186, 593-608. 
843 Erisman, J.W., Draaijers, G.P.J., Steingrover, E., Van Dijk, H., Boxman, A., de Vries, W., 844 1998. Assessment of the exposure and loads of acidifying and eutrophying pollutants 845 and ozone, as well as their, harmful influence on the vitality of the trees and the 846 Speulder forest ecosystem as a whole. Water Air Soil Pollut.105, 539-571.

847 Esmeijer-Liu, A.J., Aerts, R., Kürschner, W.M., Bobbink, R., Lotter, A.F., Verhoeven, 848 J.T.A., 2009. Nitrogen enrichment lowers Betula pendula green and yellow leaf 849 stoichiometry irrespective of effects of elevated carbon dioxide. Plant Soil 316, 311850322.

851 Feller, I.C., Lovelock, C.E., McKee, K.L., 2007. Nutrient addition differentially affects 852 ecological processes of Avicennia germinans in nitrogen versus phosphorus limited 853 mangrove ecosystems. Ecosystems 10, 347-359.

854 Fernandez, M., Novillo., C, Pardos., J.A., 2006. Effects of water and nutrient availability in 855 Pinus pinaster ait. Open pollinated families at an early age: Growth, gas exchange 856 and water relations. New For. 31, 321-3420.

857 Folk, R., Franquesa, T., Camarasa, J.M., 1984. Vegetació. Història Natural Països 858 Catalans (VII). Fundació Enciclopèdia Catalana (Ed), Barcelona.

859 Fox, J., Nie, Z., Byrnes, J., 2013. sem: Structural Equation Models.

860 Galloway, J.N., Townsend, A.R., Erisman, J.W., Bekunda, M., Cai, Z., Freney, J.R., 861 Martinelli, L.A., Seitzinger, S.P., Sutton, M.A., 2008. Transformation of the nitrogen 862 cycle: recent trends, questions, and potential solutions. Science 320, 889-892.

863 García-Palacios, P., Querejeta, J.I., Maestre, F.T., Escudero, A., Valladares, F., 2012. 864 Impact of simulated changes in rainfall regime and nutrient deposition on the relative 865 dominance and isotopic composition of ruderal plants in anthropogenic grasslands. $866 \quad$ Plant Soil 352, 303-312.

867 Garland, T.J., Harvey, P.H., Ives, A.R., 1993. Procedures for the analysis of comparative 868 data using phylogenetically independent contrast. Syst. Biol. 41, 18-320.

869 Gracia, C., Burriel, J.A., Ibàñez, J.J., Mata, T., Vayreda, J., 2004. Inventari Ecològic $i$ $870 \quad$ Forestal de Catalunya. Mètodes. Volum 9. CREAF, Bellaterra, 112 pp.

871 Graciano, C., Guiamet, J.J., Goya, J.F., 2005. Impact of nitrogen and phosphorus 872 fertilization on drought responses in Eucalyptus grandis seedlings. For. Ecol. Manag. $873212,40-49$. 
874 Gradowski, T., Thomas, S.C., 2008. Responses of Acer saccharum canopy trees and 875 saplings to $\mathrm{P}, \mathrm{K}$ and lime additions under high $\mathrm{N}$ deposition. Tree Physiol. 28, 173876 185.

877 Gress, S.E., Nichols, T.D., Northcraft, C.C., Peterjohn, W.T., 2007. Nutrient limitation in 878 soils exhibiting differing nitrogen availabilities: What lies beyond nitrogen saturation? $879 \quad$ Ecology, 88, 119-130.

880 Güsewell, S., Koerselman, W., Verhoeven, J.T.A,. 2003. Biomass N: P ratios as indicators 881 of nutrient limitation for plant populations in wetlands. Ecol. Appl. 13:372-384.

882 Güsewell, S., Bollens, U., 2003. Composition of plant species mixtures grown at various N: $883 \quad$ P ratios and levels of nutrient supply. Basic Appl. Ecol. 4:453-466.

884 Han, W., Fang, J., Guo, D., Zhang, Y., 2005. Leaf nitrogen phosphorus stoichiometry 885 across 753 terrestrial plant species in China. New Phytol. 168, 377-3850.

886 He, J.S., Wang, L., Flynn, D.F.B., Wang, X., Ma, W., Fang, J., 2008. Leaf 887 nitrogen:phosphorus stoichiometry across Chinese grassland biomes. Oecologia $888 \quad 155,301-310$.

889 Hijmans, R.J., Cameron, S.E., Parra, J.L., Jones, P.G., Jarvis, A., 2005. Very high 890 resolution interpolated climate surfaces for global land areas. Inter. J. Climat. 25, $891 \quad$ 1965-1978.

892 Huang, W.J., Zhou, G.Y., Liu, J.X., 2012. Nitrogen and phosphorus status and their 893 influence on aboveground production under increasing nitrogen deposition in three 894 successional forests. Acta Oecol. 44:20-27.

895 Inclan, R., Gimeno, B.S., Dizengremel, P., Sanchez, M., 2005. Compensation processes 896 of Aleppo pine (Pinus halepensis Mill.) to ozone exposure and drought stress. $897 \quad$ Environ. Pollut. 137, 517-524.

898 IPCC, 2007 Climate Change 2007: The Physical Science Basis. Contribution of Working 899 Group I In: Fourth Assessment Report of the Intergovernmental Panel on Climate 900 Change. (eds Solomon, S., Qin, D., Manning, M., Chen, Z., Marquis, M., Averyt, 901 K.B., Tignor, M., Miller, H.L. Cambridge University Press, Cambridge, United 902 Kingdom and New York, NY, USA.

903 Jarvis, P., Rey, A., Petsikos, C., Wintage, L., Rayment, M., Pereira, J., Bauza, J., David, 904 J., Miglietta, F., Borghetti, M., Manca, G., Valentini, R., 2007. Drying and rewetting of 
905 Mediterranean soils stimulates decomposition and carbon dioxide emission: the 906 "birch effect". Tree Physiol. 27, 929-940.

907 Johnson, H.E., Broadhurst, D., Gooddacre, R., Smith, A.R., 2003. Metabolic fingerprinting 908 of salt-stressed tomatoes. Phytochemistry 62, 919-928.

909 Jonard, M., Legout, A., Nicolas, M., Dambrine, N., Claude, E., Ulrich, E., van der Perre, R., 910 Ponette, Q., 2012. Deterioration of Norway spruce vitality despite a sharp decline in 911 acid deposition: a long-term integrated perspective. Global Change Biol. 18, 711912725.

913 Jönsson, U., Jung, T., Sonesson, K., Rosengren, U., 2005. Relationships between health 914 of Quercus robur, occurrence of Phytophthora species and site conditions in 915 southern Sweden. Plant Pathol. 54, 502-511.

916 Kang, H.Z., Zhuang, H.L., Wu, L.L., Liu, Q.L., Shen, G.R., Berg, B., Man, R.Z., Liu, C.J., 917 2011. Variation in leaf nitrogen and phosphorus stoichiometry in Picea abies across 918 Europe: An analysis based on local observations. For. Ecol. Manag. 261, 195-202.

919 Kembel, S.W., Cowan, P.D., Helmus, M.R., Cornwell, W.K., Morlon, H., Ackerly, D.D., 920 Blomberg, S.P., Webb, C.O., 2010. Picante: R tools for integrating phylogenies and 921 ecology. Bioinformatics, 26, 1463-1464.

922 Kerkhoff, A.J., Enquist, B.J., Elser, J.J., Fagan, W.F., 2005. Plant allometry, stoichiometry 923 and the temperature - dependence of primary productivity. Global Ecol. Biogeogr. $924 \quad 14,585-598$.

925 Koptsik, G.N., Lukina, N.V., Smirnova, I.E., 2007. The effect of industrial aerial pollution on 926 the composition of soil solutions in podzols. Eurasian Soil Sci. 40, 203-214.

927 Kreyling, J., Beierkuhnlein, C., Jentsch, A., 2010. Effects of soil freeze-thaw cycles differ 928 between experimental plant communities. Basic Appl. Ecol. 11, 65-75.

929 Hailes, K.J., Aitken, R.L., Menzies, N.W., 1997. Magnesium in tropical and subtropical 930 soils from north-eastern Australia. 1. Magnesium fractions and interrelationships with 931 soil properties. Australian J. Soil Res. 35, 615-627.

932 Harvey, H.P., van den Driessche, R., 1999. Nitrogen and potassium effects on xylem 933 cavitation and water-use-efficiency in poplars. Tree Physiol. 19:943-950. 
934 Hector, A., Schmid, B., Beierkuhnlei, C., Caldeira, M.S., Diemer, M., Dimitrakopoulos, J.A., 935 Finn, J.A., Freitas, H., Giller, P.S., Good, J., et al. 1999. Plant diversity and 936 productivity experiments in European grasslands. Science, 286, 1123-1127.

937 Huxman, TE, Smith, MD, Fay, PA, Knapp, AK, Shaw, MR, Loik, ME, Smith, SD, Tissue, 938 DT, Zak, JC, Weltzin, JF, et al. 2004 Convergence acroos biomes to a common rain939 use efficiency. Nature 429, 651-654.

940 Lapenis, A.G., Lawrence, G.B., Heim, A., Zheng, C.Y., Shortle, W., 2013. Climate warming 941 shifts carbon allocation from stemwood to roots in calcium-depleted spruce forests. 942 Global Biogeochem. Cycles 27. DOI: 10.1029/2011GB004268.

943 Laus, M.N., Soccio, M., Trono, D., Liberatore, M.T., Pastore, D., 2011. Activation of the 944 plant mitochondrial potassium channel by free fatty acids and acyl-CoA esters: a 945 possible defense mechanism in the response to hyperosmotic stress. J. Exp. Bot. $946 \quad 62,141-154$.

947 Lawniczak, A.E., Gusewell, S., Verhoeven, J.T.A., 2009. Effect of N:K supply ratios on 948 performance of three grass species from herbaceous wetlands. Basic Appl. Ecol. 10, $949 \quad 715-725$.

950 Lévy, G., Bréchet, C., Becker, M., 1996. Element analysis of tree rings in pedunculate oak 951 heartwood: an indicator on historical trends in the soil chemistry, related to 952 atmospheric deposition. An. Sci. For. 53, 685-696.

953 Lilleskov, E.A., Fahey, T.J., Horton, T.R., Lovett, G.M., 2002. Belowground 954 actomycorrhizal fungal community change over a nitrogen deposition gradient in $955 \quad$ Alaska. Ecology 83, 104-115.

956 Lomský, B., Srámek, V., Novotný, R., 2012. Changes in the air pollution load in the Jizera 957 Mts.: effects on the health status and mineral nutrition of the young Norway spruce 958 stands. Eur. J. For. Res. 131, 757-771.

959 Lovelock, C.E., Feller, I.C., Ball, M.C., Ellis, J., Sorell, B., 2007. Testing the growth rate vs. 960 geochemical hypothesis for latitudinal variation in plant nutrients. Ecol. Lett. 10, $961 \quad 1154-11630$.

962 Lucas, R.W., Klaminder, J., Futter, M.N., Bishop, K.H., Egnell, G., Laudon, H., Högberg, 963 P., 2011. A meta-analysis of the effects of nitrogen additions on base cations: 964 implications for plants, soils, and streams. For. Ecol. Manag. 262, 95-104. 
965 Matías, L., Castro, J., Zamora, R., 2010 Soil-nutrient availability under a global-change 966 scenario in a Mediterranean mountain ecosystem. Global Change Biol, 17, 1646$967 \quad 1657$.

968 Matzek, V., Vitousek, P.M., 2009. N : P stoichiometry and protein : RNA ratios in vascular 969 plants: an evaluation of the growth-rate hypothesis. Ecol. Lett. 12, 765-771.

970 Menut, L., Bessagnet, B., Khvorostyanov, D., Beekmann, M., Blond, N., Colette, A., Coll, 971 I., Curci, G., Foret, G., Hodzic, A., Mailler, S., Meleux, F., Monge, J.L., Pison, I., 972 Siour, G., Turquety, S., Valari, M., Vautard, R., Vivanco, M.G., 2013. CHIMERE 973 2013: a model for regional atmospheric composition modeling. Geoscience. Model 974 Develop. 6, 981-1028.

975 Milla, R., Castro-Díez, P., Maestro-Martínez, M., Montserrat-Martí, G., 2005. Relationship 976 between phenology and the remobilization of nitrogen, phosphorus and potassium in 977 branches of eight Mediterranean evergreens. New Phytol. 168, 167-178.

978 Mitchell-Olds, T., 1986. Jackknife, bootstrap and other resampling methods in regression 979 analysis. Ann. Stat. 14, 1316-1318.

980 Naples, B.K., Fisk, M.C., 2010. Belowground insights into nutrient limitation in northern 981 hardwood forests. Biogeochemistry 97, 109-121.

982 Nilsen, P., Abrahamsen, G., 2003. Scots pine and Norway spruce stands responses to 983 annual N, P and Mg fertilization. For. Ecol. Manag. 174, 221-232.

984 Ninyerola, M., Pons, X., Roure, J.M., 2005. Atlas climático digital de la Península Ibérica. 985 Metodología y aplicaciones en la biotecnología y geobotánica. ISBN 932860-8-7. 986 Universidad Autònoma de Barcelona.

987 Oddo, E., Inzerillo, S., La Bella, F., Grisafi, F., Salleo, S., Nardini, A., Goldstein, G., 2011. 988 Short-term effects of potassium fertilization on hydraulic conductance of Laurus 989 nobilis L. Tree Physiol. 31, 131-138.

990 Olde Venterink, H, Van der Vliet, RE, Wassen, MJ, 2001 Nutrient limitation along a 991 productivity gradient in wet meadows. Plant Soil 234, 171-179.

992 Olde Venterink, H., Kardel, I., Kotowski, W., Peeters, W., Wassen, M.J., 2009. Long-term 993 effects of drainage and hay-removal on nutrient dynamics and limitation in the 994 Biebrza mires, Poland. Biogeochemistry 93, 235-252. 
995 Ordoñez, J.C., van Bodegom, P.M., Witte, J.P.M., Wright, I.J., Reich, P.B., Aerts, R., 2009 996 A global study of relationships between leaf traits, climate and soil measures of 997 nutrient fertility. Global Ecol. Biogeogr. 18, 137-149.

998 Paoli, G.D., Curran, L.M., Zak, D.R., 2005. Phosphorus efficiency of Bornean rain forest 999 productivity: evidence against the unimodal efficiency hypothesis. Ecology 86, 1548$1000 \quad 1561$.

1001 Paradis, E., Claude, J., Strimmer, K., 2004. APE: analyses of phylogenetics and evolution 1002 in R language. Bioinformatics, 20, 289-290.

1003 Pedersen, L.B., Bille-Hansen, J., 1995. Effects of nitrogen load to the forest floor in stika 1004 spruce stands (Picea sitchensis) as affected by difference in deposition and spruce 1005 aphid infestations. Water Air Soil Pollut. 85, 1173-1178.

1006 Peñuelas, J., Filella, I., 2001. Herbaria century record of increasing eutrophication in 1007 Spanish terrestrial ecosystems. Global Change Biol. 7, 427-433.

1008 Peñuelas, J., Filella, I., Sabaté, S., Gracia, C., 2005. Natural systems: terrestrial 1009 ecosystems. p 517-553 In: J.E. Llebot, (ed.). Report on Climate Change in Catalonia. $1010 \quad$ Institut d'Estudis Catalans, Barcelona.

1011 Peñuelas, J., Sardans, J., Ogaya, R., Estiarte, M., 2008. Nutrient stoichiometric relations 1012 and biogeochemical niche in coesxisting plant species: effect of simulated climatic 1013 change. Pol. J. Ecol. 56, 613-622.

1014 Peñuelas, J., Sardans, J., 2009. Elementary factors. Nature 460, 803-804.

1015 Peñuelas, J., Sardans, J., Llusia, J., Owen, S., Carnicer, J., Giambelluca, T.W., Rezende, 1016 E.L., Waite, M., Niinemets, Ü., 2010. Faster returns on "leaf economics" and different 1017 biogeochemical niche in invasive compared with native plant species. Global 1018 Change Biol. 16, 2171-2185.

1019 Peñuelas, J., Sardans, J., Rivas-Ubach, A., Janssens, I.A., 2012. The human-induced 1020 imbalance between C, N and P in Earth's life system. Global Change Biol. 189, 5-8.

1021 Peñuelas, J, Poulter, B, Sardans, J., Ciais, P., van der Velde, M., Bopp, L., Boucher, O., 1022 Godderis, Y., Llusia, J., Nardin, E., Vicca, S., Obersteiner, M., Janssens, I.A., 2013a. 1023 Human-induced nitrogen-phosphorus imbalances alter natural and managed 1024 ecosystems across the globe. Nature Commun. 4, 2934. 
1025 Peñuelas, J., Sardans, J., Estiarte, M., Ogaya, R., Carnicer, J., Coll, M., Barbeta, A., 1026 Rivas-Ubach, A., Llusia, J., Garbulsky, M., Filella, I., Jump, A.S., 2013b. Evidence of 1027 current impact of climate change on life on Earth: a walk from genes to the 1028 biosphere. Global Change Biol. 19, 2303-2338

1029 Phoenix, G.K., Booth, R.E., Leake, J.R., Read, D.J., Grime, R.J., Lee, J.A., 2004. 1030 Simulated pollutant nitrogen deposition increases $\mathrm{P}$ demand and enhances root1031 surface phosphatise activities of three plant functional types in a calcareous 1032 grassland. New Phytol. 161, 279-289.

1033 Piatek, K.B., Munasinghe, P., Peterjohn, W.T., Adams, M.B., Cumming, J.R., 2009. Oak 1034 contribution to litter nutrient dynamics in an Appalachian forest receiving elevated 1035 nitrogen and dolomite. Can. J. For. Res. 39, 936-944.

1036 Pons, X., 2009. MiraMon. Geographic Information System and Remote Sensingsoftware. 1037 Centre de Recerca Ecològica i Aplicacions Forestals, CREAF. Barcelona, Spain. 1038 ISBN: 84-931323-5-7.

1039 Qadir, A., Malik, R.N., Husain, S.Z., 2008. Spatio-temporal variations in water quality of $1040 \quad$ Nullah Aik-tributary of the river Chenab, Pakistan. Environ Monit Assess 140:43-59.

1041 Raamsdonk, L.M., Teusink, B., Broadhurst, D., Zhang, N.S., Hayes, A., Walsh, M.C., 1042 Berden, J.A., Brudle, K.M., Kell, D.K., Rowland, J.J., Westerhoff, H.V., van Dam, K., 1043 Oliver, S.G., 2001. A functional genomics strategy that uses metabolome data to 1044 reveal the phenotype of silent mutations. Nature Biotechnol. 19, 45-50.

1045 R Development Core Team, 2011. R: A language and environment for statistical 1046 computing. R Foundation for Statistical Computing, Vienna, Austria. ISBN 3-9000511047 07-0, URL http://www.R-project.org/.

1048 Reich, P.B., Oleksyn, J., 2004. Global patterns of plant leaf N and P in relation to 1049 temperature and latitude. Proc. Natl. Acad. Sci. USA 101, 1101-1106.

1050 Reisner, J, Rasmussen, RJ, Bruintjes, RT, 1998 Explicit forecasting of supercooled liquid 1051 water in winter storms using the MM5 mesoscale model. Quart. J. Roy. Meteor. Soc. 1052 124B, 1071-1107.

1053 R Development Core Team, 2011. R: A language and environment for statistical 1054 computing. R Foundation for Statistical Computing, Vienna, Austria. ISBN 3-9000511055 07-0, URL http://www.R-project.org/. 
1056 Ripullone, F., Lauteri, M., Grassi, G., Amato, M., Borghetti, M., 2004. Variation in nitrogen

1057 supply changes water use efficiency of Pseudotsuga menziesii and Populus $\mathrm{X}$

1058 euroamericana; a comparison of three approaches to determine water-use

1059 efficiency. Tree Physiol. 24, 671-679.

1060 Rivas-Martínez, S., Fernández-González, F., Loidi, J., Lousa, M., Penas, A., 2001.

1061 Syntaxonomical Checklist of vascular plant communities of Spain and Portugal to

1062 association level. Itinera Geobot. 14, 5-341.

1063 Rivas-Ubach, A., Sardans, J., Pérez-Trujillo, M., Estiarte, M., Peñuelas, J., 2012. Strong

1064 relationship between elemental sotichiometry and metabolome. Proc. Natl. Acad.

1065 Sci. U.S.A. 109, 4181-4186.

1066 Roem, W.J., Berendse, F., 2000. Soil acidity and nutrient supply ratio as possible factors

1067 determining changes in plant species diversity in grassland and heathland

1068 communities. Biol. Conser. 92, 151-161.

1069 Sabaté, S., Gracia, C., Sánchez, A., 2002. Likely effects of climate change on growth of

1070 Quercus ilex, Pinus halepensis, Pinus pinaster, Pinus sylvestris and Fagus sylvatica

1071 forests in the Mediterranean region. For .Ecol. Manag. 162, 23-37.

1072 Santiago, L.S., Kitajima, K, Wright, S.J., Mulkey, S.S., 2004. Coordinated changes in

1073 photosynthesis, water relations and leaf nutritional traits of canopy trees along a

1074 precipitation gradient in lowland tropical forest. Oecologia 139, 495-502.

1075 Sandel, B., Goldstein, L.J., Kraft, N.J.B., Okie, J.G., Shuldman, M.I., Ackerly, D.D., 1076 Cleland, E.E., Suding, K.N., 2010. Contrasting trait responses in plant communities 1077 to experimental and geographic variation in precipitation. New Phytol. 188, 565-575.

1078 Sanz, M.J., Carratala, A., Gimeno, C., Millan, M.M., 2002. Atmospheric nitrogen deposition 1079 on the east coast of Spain: relevance of dry deposition in semi-arid Mediterranean 1080 regions. Environ. Pollut. 118, 259-272.

1081 Sardans, J., Peñuelas, J., 2005. Drought decreases soil enzyme activity in a 1082 Mediterranean Quercus ilex L. forest. Soil Biol. Biochem. 37, 455-461.

1083 Sardans, J., Peñuelas, J., Rodà, F., 2006a. Plasticity of leaf morphologic traits, leaf 1084 nutrient content, and water capture in the Mediterranean evergreen oak Quercus ilex 1085 subsp. ballota in response to fertilization and changes in competitive conditions. 1086 Écoscience, 13, 258-270. 
1087 Sardans, J., Rodà, F., Peñuelas, J., 2006b. Effects of a nutrient pulse supply on nutrient 1088 status of the Mediterranean trees Quercus ilex subsp. ballota and Pinus halepensis 1089 on different soils and under different competitive pressure. Trees 20, 619-632.

1090 Sardans, J., Peñuelas, J., Prieto, P., Estiarte, M., 2008c. Drought and warming induced 1091 changes in $\mathrm{P}$ and $\mathrm{K}$ concentration and accumulation in plant biomass and soil in a 1092 Mediterranean shrubland. Plant Soil 306, 261-271.

1093 Sardans, J., Peñuelas, J. 2007. Drought changes phosphorus and potassium 1094 accumulation patterns in an evergreen Mediterranean forest. Funct. Ecol. 21, 1911095201.

1096 Sardans, J., Peñuelas, J., 2008 Drought changes nutrient sources, content and 1097 stoichiometry in the bryophyte Hypnum cupressiforme Hedw. Growing in a 1098 Mediterranean forest. J. Bryol. 30:59-650.

1099 Sardans, J., Peñuelas, J., Ogaya, R., 2008a. Drought-Induced Changes in C and N 1100 Stoichiometry in a Quercus ilex Mediterranean For. For. Sci. 54, 513-522.

1101 Sardans, J., Peñuelas, J., Estiarte, M, Prieto, P., 2008b. Warming and drought alter C and $1102 \mathrm{~N}$ concentration, allocation and accumulation in a Mediterranean shrubland. Global 1103 Change Biol. 14, 2304-2316.

1104 Sardans, J., Peñuelas, J., Estiarte, M., 2008c. Changes in soil enzymes related to C and N 1105 cycle and in soil $\mathrm{C}$ and $\mathrm{N}$ content under prolonged warming and drought in a 1106 Mediterranean shrubland. Appl. Soil Ecol. 39, 223-235.

1107 Sardans, J., Peñuelas, J., 2010. Soil enzyme activity in a Mediterranean forest after six 1108 years of drought. Soil Sci. Soc. Am. J. 74, 838-851.

1109 Sardans, J., Rivas-Ubach, A., Peñuelas, J., 2011. Factors affecting nutrient concentration 1110 and stoichiometry of forest trees in Catalonia (NE Spain). For. Ecol. Manag. 262, $1111 \quad$ 2024-2034.

1112 Sardans, J., Rivas-Ubach, A., Peñuelas, J., 2012a. The elemental stoichiometry of aquatic 1113 and terrestrial ecosystems and its relationships with organism life style and 1114 ecosystem structure and function: a review. Biogeochemistry 111, 1-39.

1115 Sardans, J., Rivas-Ubach, A., Peñuelas, J., 2012b. The C:N:P stoichiometry of organisms 1116 and ecosystems in a changing world: a review and perspectives. Persp. Plant Ecol. 1117 Evol. Syst. 14, 33-47. 
1118 Simpson, D., Fagerli, H., Hellsten, S., Knulst, J.C., Westling, O., 2006. Comparison of 1119 modeled and monitored deposition fluxes of sulphur and nitrogen to ICP-forest sites 1120 in Europe. Biogeosciences 3, 337-355.

1121 Solberg, S., Kvindesland, S., Asmild, D., Venn, K., 2002. Crown condition and needle 1122 chemistry of Norway spruce in relation to critical loads of acidity in south-east $1123 \quad$ Norway. Water Air Soil Pollut. 140, 157-171.

1124 Spain Forestall National Inventory.

1125 http://www.magrama.gob.es/es/biodiversidad/temas/inventarios-

1126 nacionales/inventario- forestal-nacional/.

1127 Stamova, B.S., Roessner, U., Suren, S., Laudencia-Chigcuano, D., Bacic, A., Beckles, 1128 D.M., 2009. Metabolic profiling of transgenic wheat over-expressing the high1129 molecular-weight Dx5 glutein subunit. Metabolomics 5, 239-252.

1130 Stefanescu, C., Carnicer, J., Peñuelas, J., 2011. Determinants of species richness in 1131 generalist and specialist Mediterranean butterflies: the negative synergistic forces of 1132 climate and habitat change. Ecography 34, 353-363.

1133 Stone, L.F., Moreira, J.A., 1996. Response of upland rice ploughing depth, potassium 1134 fertilization, and soil water status. Pesquisa Agrop. Brasileira 31:885-895.

1135 Thelin, G., Rosengren-Brinck, U., Nihlgard, B., Barkman, A., 1998. Trends in needle and 1136 soil chemistry of Norway spruce and scotts pine stands in South Sweden 1985-1994. 1137 Environ. Pollut. 99, 149-158.

1138 Thomas, F.M., Blank, R., Hartmann, G., 2002. Abiotic and biotic factors and their 1139 interactions as causes of oak decline in Central Europe. For. Pathol. 32, 277-307.

1140 Tripler, C.E., Kaushal, S.S., Likens, G.E., Walter, M.T., 2006. Patterns in potassium 1141 dynamics in forest ecosystems. Ecol. Lett. 9, 451-466.

1142 Turner, B.L., Chudek J.A., Whitton B.A., Baxter R., 2003. Phosphorus composition of 1143 upland soils polluted by long-term atmospheric nitrogen deposition. Biogeochemistry $1144 \quad 65: 259.274$.

1145 Urbina, I., Sardans, J., Beierkuhnlein, C., Grant, K., Kreyling, J., Peñuelas, J., 2015. 1146 Changes in species richness shift species biogeochemical niche. Env. Exp. Bot. 111, $1147 \quad 63-73$. 
1148 Veresoglou, S.D., Peñuelas, J., Fischer, R., Sardans, J., Merilä, P., Takakovic-Tosic, M., 1149 Rillig, M.C., (2014) Exploring continental-scale stand health - N : P ratio relationships 1150 for European forests. New Phytol. 202, 422-430.

1151 Villaescusa, R., Díaz, R., (eds.) 1998 Segundo Inventario Forestal Nacional (1986-1996). 1152 España. Ed. Ministerio de Medio Ambiente, ICONA, Madrid.

1153 Villanueva, J.A. (ed). 2005 Tercer Inventario Forestal Nacional (1997-2007). Ed. Ministerio 1154 de Medio Ambiente. Madrid.

1155 Vitousek, P.M., Porder, S., Houlton, B.Z., Chadwick, O.A., 2010. Terrestrial phosphorus 1156 limitation: mechanisms, implications, and nitrogen-phosphorus interactions. Eco.I 1157 Appl. 20, 5-15.

1158 Vivanco, M.G., Palomino, I., Vautard, R., Bessagnet, B., Martín, F., Menut, L., Jiménez, S., 1159 2009. Multi-year assessment of photochemical air quality simulation over Spain. $1160 \quad$ Environ Model Software 24:63-73.

1161 Voesenek, L.A.C.J., Pierik, R., 2008. Plant science - Plant stress profiles. Science 320, $1162 \quad 880-881$.

1163 Wang, M., Gu, B.J., Ge, Y., Liu, Z., Jiang, D.A., Chang, S.X., Chang, J., 2009. Different 1164 responses of two Molsa species to potassium limitation in relation to acid deposition. 1165 J. Zhejiang University-Sci B 10, 563-571.

1166 Wang, D., Heckathorn, S.A., Wang, X.Z., Philpott, S.M., 2012. A meta-analysis of plant 1167 physiological and growth responses to temperature and elevated $\mathrm{CO}_{2}$. Ocologia 169 ,

1169 Watmough, S.A., Aherne, J., Alewell, C., Arp, P., Bailey, S., Clair, T., Dillon, P., Duchesne, L., Eimers, C., Fernández, I., Foster, N., Larssen, T., Miller, E., Mitchell, M., Page,

1173 Walker,T.W., Syers, J.K., 1976. The fate of phosphorus during pedogenesis. Geoderma 1174 15, 1-19.

1175 Walter, A., Schurr, U., 2005. Dynamics of leaf and root growth: endogenous control versus 1176 environmental impact. An. Bot. 95, 891-900.

1177 Webb, C.O., Donoghue, M.J., 2005. Phylomatic: tree assembly for applied phylogenetics. 1178 Mol. Ecol. Notes 5, 181-183. 
1179 Webb, C.O., Ackerly, D.D., Kembel S.W., 2008. Phylocom: software for the analysis of 1180 phylogenetic community structure and trait evolution. Bioinformatics, 24, 2098-2100.

1181 Welander, N.T., Ottosson, B., 2000. The influence of low light, drought and fertilization on 1182 transpiration and growth in young seedlings of Quercus robur L. For. Ecol. Manag. 1183 127, 139-151.

1184 Willby, N.J., Pulford, I.D., Flowers, T.H., 2001. Tissue nutrient signatures predict 1185 herbaceous-wetland community responses to nutrient availability. New Phytol. 152, 1186 463-4810.

1187 Wright, S.J., Yavitt, J.B., Wurzburger, N., Turner, B.L., Tanner, E.V.L., Sayer, E.J., 1188 Santiago, L.S., Kaspari, M., Hedin, L.O., Harms, K.E., Garcia, M.N., Corre, M.D., 1189 2011. Potassium, phosphorus, or nitrogen limit root allocation, tree growth, or litter 1190 production in a lowland tropical forest. Ecology 92, 1616-1625.

1191 Yu, Q., Chen, Q., Elser, J.J., He, N., Wu, H., Zhang, G., Wu, J., Bai, Y., Han, X.G., 2010. 1192 Linking stoichiometric homeostasis with ecosystem structure, functioning and 1193 stability. Ecol. Lett. 13, 1390-1399.

1194 Yu, Q., Elser, J.J., He, N., Wu, H., Chen, Q., Zhang, G., Han, X., 2011. Stoichiometry 1195 homeostasis of vascular plants in the inner Mongolia grassland. Oecologia 166:1-10.

1196 Yuan, Z.Y., Chen, H.Y.H., 2009. Global trends in senescend-leaf nitrogen and 1197 phosphorus. Global Ecol. Biogeogr. 18, 532-542.

1198 Zheng, S., Shangguan, Z., 2007. Soil patterns of leaf nutrient traits of the plants in the 1199 loess plateau of China. Trees 21, 357-370.

1200 
1201 Figure captions

1202 Figure 1. Distribution of the forests showing the most representative forest type of each.

1203

1204 Figure 2. Biplots representing (A) the PC1 and PC2 axes and (B) the PC1 and PC3 axes

1205 of the Principal Component Analysis conducted with log transformed foliar N, P, K, Ca, Mg

1206 and $\mathrm{S}$ concentrations and $\log$ transformed foliar $\mathrm{N}: \mathrm{P}, \mathrm{N}: \mathrm{K}$ and $\mathrm{P}: \mathrm{K}$ ratios of the main 37

1207 Spain's forest species. The relationships of all pair-wise species differences in the scores

1208 of PC1 (C), PC2 (D) and PC3 (E) with the corresponding pair-wise species phylogenetic

1209 distances.

1210

1211 Figure 3. Mean \pm SE of foliar $\mathrm{N}: \mathrm{P}, \mathrm{N}: \mathrm{K}$ and $\mathrm{P}: \mathrm{K}$ ratios in the various forest types

1212 (evergreens, Mediterranean gymnosperms, non-Mediterranean gymnosperms and

1213 deciduous forests). Different letters indicate significant differences $(P<0.05)$.

1214

1215 Figure 4. Distribution of the forest tree species as a function of the mean annual 1216 temperature (MAT) and mean annual precipitation (MAP). Large color symbols indicate the 1217 means of MAT and MAP for each forest type.

1218

1219 Figure 5. Mean \pm SE of foliar N, P and K concentrations in the various forest types

1220 (Mediterranean evergreen angiosperms, Mediterranean gymnosperms, Mediterranean

1221 deciduous forests, wet temperate and alpine gymnosperms and wet temperate deciduous

1222 angiosperms). Different letters indicate significant differences $(P<0.05)$.

1223

1224 Figure 6. Relationship of log foliar N:P ratios with $\log P$ concentrations in 4691 forest plots.

1225

1226 Figure 7. Relationships of $(\mathrm{A}) \log$ foliar $N$ concentration (\%, DW), (B) $\log$ foliar $\mathrm{P}$ 1227 concentration (\%, DW), (C) foliar N:P ratio and (D) log foliar $\mathrm{K}$ concentration (\%, DW) with $1228 \log \mathrm{N}$ deposition ( $\mathrm{mg} \mathrm{m}^{-2} \mathrm{y}^{-1}$ ).

1229 
1230 Figure 8. Relationships between log soil N-Kejdahl concentration and log $\mathrm{N}$ deposition

1231 across 53 plots of Spain (ICP forest data).

1232

1233 Figure 9. Structural-path model with climate (MAT and MAP) and taxonomy (angiosperms 1234 versus gymnosperms) as exogenous variables and $\mathrm{N}$ deposition, foliar $\mathrm{N}$ and $\mathrm{P}$ 1235 concentrations and foliar N:P ratio as endogenous variables. Number next to each arrow 1236 indicates the Pearson $\mathrm{R}$ coefficient between the two corresponding variables and the 1237 number below it (between brackets) indicates the corresponding level of significance ( $P$ 1238 value).

1240 Figure 10. Total, direct and indirect effects of $\mathrm{N}$ deposition ( $\mathrm{N}$ dep), MAP, MAT, foliar $\mathrm{N}$ 1241 concentration (foliar $[N]$ ), foliar $\mathrm{P}$ concentrations (foliar $[\mathrm{P}]$ ) and (angiosperms versus 1242 gymnosperms, converted in a dummy variable, 0 = angiosperms, 1 = gymnosperms) on 1243 foliar $\mathrm{N}$ concentration, foliar $\mathrm{P}$ concentrations and foliar $\mathrm{N}: \mathrm{P}$ ratio. Data obtained by using 1244 the bootstrap (with 1200 repetitions) technique (Davison et al., 1986; Mitchell-Olds, 1986).

1246 Figure 11. Loadings (A) and scores (B) of the PCA conducted using log foliar N, P, K, Ca, $1247 \mathrm{~S}$ and $\mathrm{Mg}$ concentrations and $\mathrm{N}: \mathrm{P}, \mathrm{N}: \mathrm{K}$ and $\mathrm{P}: \mathrm{K}$ ratios as variables and the data from 260 1248 plots from the ICP forest dataset with the 13 most representative Mediterranean tree 1249 species of Spanish forests. The mean values and corresponding SEs of the PC1 and PC2 1250 scores for each forest type are presented in panel (B). Statistically significant differences in 1251 scores among species are indicated by different letters along the corresponding axes. (C) 1252 Relationship of PC2 scores with log N deposition.

1253

1254 Figure 12. Relationships of the differences in PC1 scores (obtained by using log 1255 transformed foliar $\mathrm{N}, \mathrm{P}, \mathrm{K}, \mathrm{Ca}, \mathrm{Mg}$ and $\mathrm{S}$ concentrations and log transformed foliar $\mathrm{N}: \mathrm{P}$, $1256 \mathrm{~N}: \mathrm{K}$ and $\mathrm{P}: \mathrm{K}$ ratios as variables) between pairwise species and the corresponding pairwise 1257 species overlapping frequency (coincident in the same community) ( $0=$ no overlapping, 1 1258 = occasionally overlapping, 2 = moderate overlapping, 3 = frequent overlapping) for the 13 1259 most representative Mediterranean species (Rivas-Martinez et al., 2001; De Bolos and 1260 Vigo 2001; CREAF, Catalonia cover map, 2013; and Folk et al. 1984). 
1261 Table 1. Species included in the study.

1262

\section{Forest tree species}

\section{Mediterranean evergreen angiosperms}

Arbutus unedo, Eucalyptus sp., Ilex aquifolium, Olea europea, Quercus ilex, Quercus suber.

\section{Mediterranean deciduous angiosperms}

Castanea sativa, Quercus canariensis, Quercus canariensis x humilis, Quercus cerrioides, Quercus cerrioides x humilis, Quercus faginea, Quercus pyrenaica.

\section{Wet temperate deciduous angiosperms}

Betula pendula, Fagus sylvatica, Fraxinus angustifolia, Fraxinus excelsior, Platanus hybrides, Populus nigra, Populus tremula, Prunus malaheb, Quercus humilis, Quercus petraea, Quercus robur.

\section{Mediterranean gymnosperms}

Juniperus oxycedrus, Juniperus phoenica, Juniperus thurifera, Pinus halepensis, Pinus nigra, Pinus pinaster, Pinus pinea.

\section{Wet temperate and alpine gymnosperms}

Abies alba, Cedrus deodorata, Pinus radiata, Pinus sylvestris, Pinus uncinata, Pseudotsuga menziesi. 
1265 Table 2. Phylogenetic signals (Webb and Donoghue 2005; Webb, Ackerly, and Kembel 1266 2008) of different variables and of PC-axes scores of the PCA conducted with overall log 1267 transformed foliar elemental compositions ( $\mathrm{N}, \mathrm{P}, \mathrm{K}, \mathrm{Ca}, \mathrm{Mg}$ and $\mathrm{S}$ concentrations and log 1268 transformed foliar N:P, N:K and P:K ratios as variables) of the most representative 37 1269 species of Spanish forests. The variables with significant $(P<0.05)$ phylogenetic signals are 1270 highlighted in bold type ( $K=$ statistic, $P=$ level of signification).

\begin{tabular}{|c|c|c|}
\hline \multirow{2}{*}{ Variable } & \multicolumn{2}{|c|}{ Phylogenetic signal statistics } \\
\cline { 2 - 3 } & $K$ & $P$ \\
\hline Foliar [N] & $\mathbf{0 . 1 7 1}$ & $\mathbf{0 . 0 0 1}$ \\
\hline Foliar [P] & 0.114 & 0.065 \\
\hline Foliar [K] & $\mathbf{0 . 1 8 2}$ & $\mathbf{0 . 0 0 6}$ \\
\hline Foliar [Ca] & $\mathbf{0 . 2 0 4}$ & $\mathbf{0 . 0 0 2}$ \\
\hline Foliar [Mg] & 0.105 & 0.25 \\
\hline Foliar [S] & $\mathbf{0 . 2 1 6}$ & $\mathbf{0 . 0 0 4}$ \\
\hline Foliar N:P ratio & 0.135 & 0.31 \\
\hline Foliar N:K ratio & 0.085 & 0.73 \\
\hline Foliar P:K ratio & 0.174 & 0.09 \\
\hline PC1 & $\mathbf{0 . 1 7 0}$ & $\mathbf{0 . 0 4}$ \\
\hline PC2 & 0.117 & 0.074 \\
\hline PC3 & $\mathbf{0 . 2 5 6}$ & $\mathbf{0 . 0 0 2}$ \\
\hline PC4 & $\mathbf{0 . 1 6 5}$ & $\mathbf{0 . 0 0 2}$ \\
\hline PC5 & 0.144 & 0.11 \\
\hline PC6 & 0.093 & 0.60 \\
\hline
\end{tabular}

1271 
1272 Table 3. Coefficients of correlation $(R)$ and levels of significance $(P)$ of the correlations of 1273 foliar $\mathrm{N}$ and $\mathrm{P}$ concentrations and N:P ratios with MAP and MAT. All variables were log1274 transformed. Bold type indicates statistically significant correlations at $P<0.01$.

\begin{tabular}{|l|l|l|l|l|}
\hline \multicolumn{2}{|l|}{ Climatic data } & $\begin{array}{l}\text { log foliar N } \\
\text { concentration }\end{array}$ & $\begin{array}{l}\text { log foliar P } \\
\text { concentration }\end{array}$ & log foliar N:P ratio \\
\hline $\begin{array}{l}\text { Data from } \\
\text { WorldClim } \\
\text { database }\end{array}$ & $\log$ MAP & $R=0.14$ & $R=0.24$ & $R=-0.13$ \\
\cline { 2 - 5 } & $P<0.001$ & $P<0.0001$ & $P<0.001$ \\
\hline $\begin{array}{l}\text { Data from } \\
\text { Atlas } \\
\text { Climatico } \\
\text { digital de } \\
\text { España }\end{array}$ & $\log$ MAP & $R=0.40$ & $R=-0.17$ & $R=0.24$ \\
\cline { 2 - 5 } & $\log$ MAT & $R=0.007$ & $P<0.0001$ & $P<0.0001$ \\
\hline & $P<0.001$ & $R=0.28$ & $R=-0.045$ \\
& $P=0.051$ & $R=0.001$ & $P=0.002$ \\
\hline
\end{tabular}


1289 Table 4. Test statistics for squared Mahalanobis distances between all pairwise comparisons of tree species from the discriminate 1290 functional analysis with log-transformed foliar concentrations of $\mathrm{N}, \mathrm{P}, \mathrm{K}, \mathrm{S}, \mathrm{Ca}$ and $\mathrm{Mg}$ and log-transformed N:P, N:K and P:K 1291 concentration ratios as variables using the 375 plots from the ICP data set dominated by the 21 most representative species of forest 1292 trees as cases. Significant pairwise distances are highlighted in bold type.

\begin{tabular}{|c|c|c|c|c|c|c|c|c|c|c|c|c|c|c|c|c|c|c|c|c|}
\hline & $\begin{array}{c}\text { B. } \\
\text { pendula }\end{array}$ & C. sativa & $\begin{array}{c}\text { Eucalyptus } \\
s p\end{array}$ & $\begin{array}{c}F . \\
\text { sylvatica }\end{array}$ & $\begin{array}{c}\mathrm{J} . \\
\text { oxycedrus }\end{array}$ & \begin{tabular}{c|}
$\mathrm{J}$. \\
thurifera
\end{tabular} & $\begin{array}{c}0 . \\
\text { europea }\end{array}$ & $\begin{array}{c}P . \\
\text { halepensis }\end{array}$ & P. nigra & \begin{tabular}{c|}
$P$. \\
pinaster
\end{tabular} & P. pinea & $\begin{array}{c}P . \\
\text { sylvestris }\end{array}$ & P. uncinata & Q. faginea & Q. humilis & Q. ilex & $\begin{array}{c}Q . \\
\text { petraea }\end{array}$ & Q. pyrenaica & Q. robur & Q. suber \\
\hline A. alba & $\begin{array}{c}41.5 \\
P<0.001\end{array}$ & $\begin{array}{c}50.6 \\
P<0.001\end{array}$ & $\begin{array}{c}15.1 \\
P<0.001\end{array}$ & $\begin{array}{c}33.1 \\
P<0.001\end{array}$ & $\begin{array}{c}10.8 \\
P=0.16\end{array}$ & $\begin{array}{c}6.11 \\
P=0.23\end{array}$ & $\begin{array}{c}12.2 \\
P=0.04\end{array}$ & $\begin{array}{c}43.0 \\
P<0.001\end{array}$ & $\begin{array}{c}35.5 \\
P<0.001\end{array}$ & $\begin{array}{c}65.1 \\
P<0.001\end{array}$ & $\begin{array}{c}74.3 \\
P<0.001\end{array}$ & $\begin{array}{c}32.0 \\
P<0.001\end{array}$ & $\begin{array}{c}45.5 \\
P<0.001\end{array}$ & $\begin{array}{c}27.5 \\
P<0.001\end{array}$ & $\begin{array}{c}25.4 \\
P<0.001\end{array}$ & $\begin{array}{c}17.1 \\
P<0.001\end{array}$ & $\begin{array}{c}27.5 \\
P<0.001\end{array}$ & $\begin{array}{c}32.0 \\
P<0.001\end{array}$ & $\begin{array}{c}39.8 \\
P<0.001\end{array}$ & $\begin{array}{c}27.1 \\
P<0.001\end{array}$ \\
\hline B. pendula & & $\begin{array}{c}3.64 \\
P=0.74\end{array}$ & $\begin{array}{c}16.7 \\
P<0.001\end{array}$ & $\begin{array}{c}12.5 \\
P<0.001\end{array}$ & $\begin{array}{c}55.2 \\
P<0.001\end{array}$ & $\begin{array}{c}40.7 \\
P<0.001\end{array}$ & $\begin{array}{c}40.9 \\
P<0.001\end{array}$ & $\begin{array}{c}23.3 \\
P<0.001\end{array}$ & $\begin{array}{c}35.7 \\
P<0.001\end{array}$ & $\begin{array}{c}45.6 \\
P<0.001\end{array}$ & $\begin{array}{c}39.6 \\
P<0.001\end{array}$ & $\begin{array}{c}23.4 \\
P<0.001\end{array}$ & $\begin{array}{c}40.7 \\
P<0.001\end{array}$ & $\begin{array}{c}8.97 \\
P<0.001\end{array}$ & $\begin{array}{c}18.6 \\
P<0.001\end{array}$ & $\begin{array}{c}17.3 \\
P<0.001\end{array}$ & $\begin{array}{c}14.1 \\
P=0.005\end{array}$ & $\begin{array}{c}3.15 \\
P=0.29\end{array}$ & $\begin{array}{c}8.69 \\
P=0.01\end{array}$ & $\begin{array}{c}8.74 \\
P=0.004\end{array}$ \\
\hline C. sativa & & & $\begin{array}{c}27.3 \\
P<0.001\end{array}$ & $\begin{array}{c}16.6 \\
P<0.001\end{array}$ & $\begin{array}{c}73.4 \\
P<0.001\end{array}$ & $\begin{array}{c}49.1 \\
P<0.001\end{array}$ & $\begin{array}{c}56.1 \\
P<0.001\end{array}$ & $\begin{array}{c}39.8 \\
P<0.001\end{array}$ & $\begin{array}{c}50.1 \\
P<0.001\end{array}$ & $\begin{array}{c}63.8 \\
P<0.001\end{array}$ & $\begin{array}{c}57.0 \\
P<0.001\end{array}$ & $\begin{array}{c}33.8 \\
P<0.001\end{array}$ & $\begin{array}{c}52.1 \\
P<0.001\end{array}$ & $\begin{array}{c}12.6 \\
P<0.001\end{array}$ & $\begin{array}{c}22.9 \\
P<0.001\end{array}$ & $\begin{array}{c}27.5 \\
P<0.001\end{array}$ & $\begin{array}{c}16.4 \\
P=0.008\end{array}$ & $\begin{array}{c}3.74 \\
P=0.44\end{array}$ & $\begin{array}{c}14.1 \\
P=0.004\end{array}$ & $\begin{array}{c}16.8 \\
P<0.001\end{array}$ \\
\hline Eucalyptus sp. & & & & $\begin{array}{c}21.5 \\
P<0.001\end{array}$ & $\begin{array}{c}16.4 \\
P=0.02\end{array}$ & $\begin{array}{c}13.6 \\
P<0.001\end{array}$ & $\begin{array}{c}16.0 \\
P<0.001\end{array}$ & $\begin{array}{c}20.6 \\
P<0.001\end{array}$ & $\begin{array}{c}26.9 \\
P<0.001\end{array}$ & $\begin{array}{c}44.6 \\
P<0.001\end{array}$ & $\begin{array}{c}40.2 \\
P<0.001\end{array}$ & $\begin{array}{c}23.3 \\
P<0.001\end{array}$ & $\begin{array}{c}41.6 \\
P<0.001\end{array}$ & $\begin{array}{c}7.15 \\
P<0.001\end{array}$ & $\begin{array}{c}12.8 \\
P<0.001\end{array}$ & $\begin{array}{c}7.30 \\
P<0.001\end{array}$ & $\begin{array}{c}23.9 \\
P<0.001\end{array}$ & $\begin{array}{c}15.7 \\
P<0.001\end{array}$ & $\begin{array}{c}22.7 \\
P<0.001\end{array}$ & $\begin{array}{c}7.24 \\
P<0.001\end{array}$ \\
\hline F. sylvatica & & & & & $\begin{array}{c}44.0 \\
P<0.001\end{array}$ & $\begin{array}{c}30.7 \\
P<0.001\end{array}$ & $\begin{array}{c}22.8 \\
P<0.001\end{array}$ & $\begin{array}{c}49.2 \\
P<0.001\end{array}$ & $\begin{array}{c}54.4 \\
P<0.001\end{array}$ & $\begin{array}{c}79.2 \\
P<0.001\end{array}$ & $\begin{array}{c}76.3 \\
P<0.001\end{array}$ & $\begin{array}{c}34.6 \\
P<0.001\end{array}$ & $\begin{array}{c}49.5 \\
P<0.001\end{array}$ & $\begin{array}{c}9.10 \\
P<0.001\end{array}$ & $\begin{array}{c}6.88 \\
P=0.02\end{array}$ & $\begin{array}{c}19.3 \\
P<0.001\end{array}$ & $\begin{array}{c}2.36 \\
P=0.60\end{array}$ & $\begin{array}{c}6.28 \\
P<0.001\end{array}$ & $\begin{array}{c}1.65 \\
P=0.51\end{array}$ & $\begin{array}{c}15.3 \\
P<0.001\end{array}$ \\
\hline J. oxycedrus & & & & & & $\begin{array}{c}8.18 \\
P<0.001\end{array}$ & $\begin{array}{c}11.6 \\
P=0.06\end{array}$ & $\begin{array}{c}39.5 \\
P<0.001\end{array}$ & $\begin{array}{c}40.3 \\
P<0.001\end{array}$ & $\begin{array}{c}66.5 \\
P<0.001\end{array}$ & $\begin{array}{c}73.7 \\
P<0.001\end{array}$ & $\begin{array}{c}40.0 \\
P<0.001\end{array}$ & $\begin{array}{c}54.9 \\
P<0.001\end{array}$ & $\begin{array}{c}36.8 \\
P<0.001\end{array}$ & $\begin{array}{c}34.8 \\
P<0.001\end{array}$ & $\begin{array}{c}21.8 \\
P<0.001\end{array}$ & $\begin{array}{c}45.7 \\
P<0.001\end{array}$ & $\begin{array}{c}50.1 \\
P<0.001\end{array}$ & $\begin{array}{c}51.1 \\
P<0.001\end{array}$ & $\begin{array}{c}35.4 \\
P<0.001\end{array}$ \\
\hline J. thurifera & & & & & & & $\begin{array}{c}11.5 \\
P<0.001\end{array}$ & $\begin{array}{c}44.6 \\
P<0.001\end{array}$ & $\begin{array}{c}49.7 \\
P<0.001\end{array}$ & $\begin{array}{c}80.0 \\
P<0.001\end{array}$ & $\begin{array}{c}86.2 \\
P<0.001\end{array}$ & $\begin{array}{c}43.6 \\
P<0.001\end{array}$ & $\begin{array}{c}61.1 \\
P<0.001\end{array}$ & $\begin{array}{c}23.4 \\
P<0.001\end{array}$ & $\begin{array}{c}20.7 \\
P<0.001\end{array}$ & $\begin{array}{c}23.1 \\
P<0.001\end{array}$ & $\begin{array}{c}28.0 \\
P<0.001\end{array}$ & $\begin{array}{c}31.3 \\
P<0.001\end{array}$ & $\begin{array}{c}40.4 \\
P<0.001\end{array}$ & $\begin{array}{c}32.3 \\
P<0.001\end{array}$ \\
\hline O. europea & & & & & & & & $\begin{array}{c}50.8 \\
P<0.001\end{array}$ & $\begin{array}{c}56.7 \\
P<0.001\end{array}$ & $\begin{array}{c}85.0 \\
P<0.001\end{array}$ & $\begin{array}{c}87.8 \\
P<0.001\end{array}$ & $\begin{array}{c}48.8 \\
P<0.001\end{array}$ & $\begin{array}{c}64.0 \\
P<0.001\end{array}$ & $\begin{array}{c}23.2 \\
P<0.001\end{array}$ & $\begin{array}{c}14.6 \\
P=0.003\end{array}$ & $\begin{array}{c}24.6 \\
P<0.001\end{array}$ & $\begin{array}{c}21.5 \\
P<0.001\end{array}$ & $\begin{array}{c}31.8 \\
P<0.001\end{array}$ & $\begin{array}{c}29.2 \\
P<0.001\end{array}$ & $\begin{array}{c}29.7 \\
P<0.001\end{array}$ \\
\hline P. halepensis & & & & & & & & & $\begin{array}{c}13.0 \\
P<0.001\end{array}$ & $\begin{array}{c}11.2 \\
P<0.001\end{array}$ & $\begin{array}{c}12.9 \\
P<0.001\end{array}$ & $\begin{array}{c}16.1 \\
P<0.001\end{array}$ & $\begin{array}{c}31.5 \\
P<0.001\end{array}$ & $\begin{array}{c}37.6 \\
P<0.001\end{array}$ & $\begin{array}{c}54.3 \\
P<0.001\end{array}$ & $\begin{array}{c}20.1 \\
P<0.001\end{array}$ & $\begin{array}{c}52.3 \\
P<0.001\end{array}$ & $\begin{array}{c}36.4 \\
P<0.001\end{array}$ & $\begin{array}{c}43.1 \\
P<0.001\end{array}$ & $\begin{array}{c}22.1 \\
P<0.001\end{array}$ \\
\hline
\end{tabular}




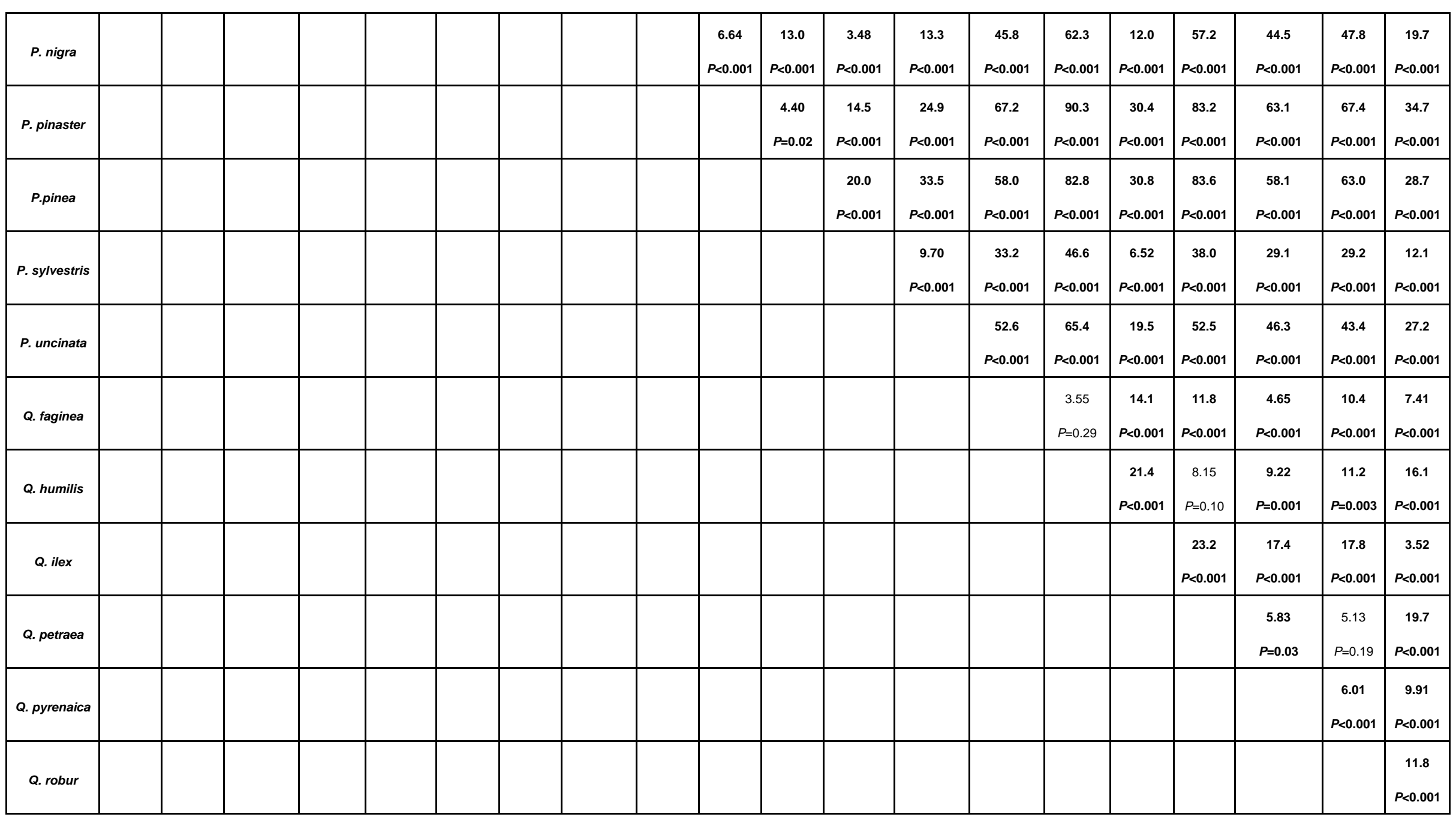


1295 Table 5. Test statistics for squared Mahalanobis distances between all pairwise comparisons of tree species from the discriminate

1296 functional analysis with log-transformed foliar concentrations of N, P, K, S, Ca and Mg and log-transformed N:P, N:K and P:K

1297 concentration ratios as variables using the 305 plots from the ICP data set dominated by the 13 most representative species of

1298 Mediterranean forest trees as cases. All pairwise distances are significant $(P<0.05)$.

\begin{tabular}{|c|c|c|c|c|c|c|c|c|c|c|c|c|}
\hline & Eucalyptus sp & J. oxycedrus & J. thurifera & O. europea & P. halepensis & P. nigra & P. pinaster & P. pinea & Q. faginea & Q. ilex & Q. pyrenaica & Q. suber \\
\hline C.sativa & $\begin{array}{c}24.6 \\
P<0.001\end{array}$ & $\begin{array}{c}66.6 \\
P<0.001\end{array}$ & $\begin{array}{c}43.7 \\
P<0.001\end{array}$ & $\begin{array}{c}50.2 \\
P<0.001\end{array}$ & $\begin{array}{c}40.4 \\
P<0.001\end{array}$ & $\begin{array}{c}52.4 \\
P<0.001\end{array}$ & $\begin{array}{c}68.1 \\
P<0.001\end{array}$ & $\begin{array}{c}60.0 \\
P<0.001\end{array}$ & $\begin{array}{c}11.2 \\
P=0.004\end{array}$ & $\begin{array}{c}26.5 \\
P<0.001\end{array}$ & $\begin{array}{c}3.38 \\
P<0.001\end{array}$ & $\begin{array}{c}15.7 \\
P<0.001\end{array}$ \\
\hline Eucalyptus sp. & & $\begin{array}{c}15.2 \\
P<0.001\end{array}$ & $\begin{array}{c}12.6 \\
P<0.001\end{array}$ & $\begin{array}{c}15.2 \\
P<0.001\end{array}$ & $\begin{array}{c}20.8 \\
P<0.001\end{array}$ & $\begin{array}{c}28.4 \\
P<0.001\end{array}$ & $\begin{array}{c}46.8 \\
P<0.001\end{array}$ & $\begin{array}{c}41.3 \\
P<0.001\end{array}$ & $\begin{array}{c}7.14 \\
P<0.001\end{array}$ & $\begin{array}{c}7.18 \\
P<0.001\end{array}$ & $\begin{array}{c}14.5 \\
P<0.001\end{array}$ & $\begin{array}{c}6.40 \\
P<0.001\end{array}$ \\
\hline J. oxycedrus & & & $\begin{array}{c}8.04 \\
P=0.04\end{array}$ & $\begin{array}{c}11.9 \\
P=0.03\end{array}$ & $\begin{array}{c}37.2 \\
P<0.001\end{array}$ & $\begin{array}{c}38.4 \\
P<0.001\end{array}$ & $\begin{array}{c}64.5 \\
P<0.001\end{array}$ & $\begin{array}{c}70.1 \\
P<0.001\end{array}$ & $\begin{array}{c}34.7 \\
P<0.001\end{array}$ & $\begin{array}{c}19.2 \\
P<0.001\end{array}$ & $\begin{array}{c}46.1 \\
P<0.001\end{array}$ & $\begin{array}{c}31.5 \\
P<0.001\end{array}$ \\
\hline J. thurifera & & & & $\begin{array}{c}10.6 \\
P<0.001\end{array}$ & $\begin{array}{c}44.2 \\
P<0.001\end{array}$ & $\begin{array}{c}50.2 \\
P<0.001\end{array}$ & $\begin{array}{c}80.9 \\
P<0.001\end{array}$ & $\begin{array}{c}84.9 \\
P<0.001\end{array}$ & $\begin{array}{c}21.2 \\
P<0.001\end{array}$ & $\begin{array}{c}21.4 \\
P<0.001\end{array}$ & $\begin{array}{c}28.0 \\
P<0.001\end{array}$ & $\begin{array}{c}29.0 \\
P<0.001\end{array}$ \\
\hline O. europea & & & & & $\begin{array}{c}51.0 \\
P<0.001\end{array}$ & $\begin{array}{c}58.9 \\
P<0.001\end{array}$ & $\begin{array}{c}88.0 \\
P<0.001\end{array}$ & $\begin{array}{c}88.6 \\
P<0.001\end{array}$ & $\begin{array}{c}20.9 \\
P<0.001\end{array}$ & $\begin{array}{c}24.1 \\
P<0.001\end{array}$ & $\begin{array}{c}28.3 \\
P<0.001\end{array}$ & $\begin{array}{c}27.5 \\
P<0.001\end{array}$ \\
\hline P. halepensis & & & & & & $\begin{array}{c}12.3 \\
P<0.001\end{array}$ & $\begin{array}{c}11.1 \\
P<0.001\end{array}$ & $\begin{array}{c}12.0 \\
P<0.001\end{array}$ & $\begin{array}{c}39.5 \\
P<0.001\end{array}$ & $\begin{array}{c}19.3 \\
P<0.001\end{array}$ & $\begin{array}{c}38.2 \\
P<0.001\end{array}$ & $\begin{array}{c}21.5 \\
P<0.001\end{array}$ \\
\hline P. nigra & & & & & & & $\begin{array}{c}6.54 \\
P<0.001\end{array}$ & $\begin{array}{c}12.4 \\
P<0.001\end{array}$ & $\begin{array}{c}49.9 \\
P<0.001\end{array}$ & $\begin{array}{c}12.9 \\
P<0.001\end{array}$ & $\begin{array}{c}48.3 \\
P<0.001\end{array}$ & $\begin{array}{c}21.2 \\
P<0.001\end{array}$ \\
\hline P. pinaster & & & & & & & & $\begin{array}{c}4.18 \\
P=0.01\end{array}$ & $\begin{array}{c}72.6 \\
P<0.001\end{array}$ & $\begin{array}{c}31.7 \\
P<0.001\end{array}$ & $\begin{array}{c}68.7 \\
P<0.001\end{array}$ & $\begin{array}{c}37.1 \\
P<0.001\end{array}$ \\
\hline
\end{tabular}




\begin{tabular}{|c|c|c|c|c|}
\hline P. pinea & $\begin{array}{c}62.2 \\
P<0.001\end{array}$ & $\begin{array}{c}31.2 \\
P<0.001\end{array}$ & $\begin{array}{c}62.1 \\
P<0.001\end{array}$ & $\begin{array}{c}30.5 \\
P<0.001\end{array}$ \\
\hline Q. faginea & & $\begin{array}{c}15.1 \\
P<0.001\end{array}$ & $\begin{array}{c}4.11 \\
P<0.001\end{array}$ & $\begin{array}{c}7.77 \\
P<0.001\end{array}$ \\
\hline Q. ilex & & & $\begin{array}{c}17.9 \\
P<0.001\end{array}$ & $\begin{array}{c}3.46 \\
P<0.001\end{array}$ \\
\hline Q. pyrenaica & & & & $\begin{array}{c}9.90 \\
P<0.001\end{array}$ \\
\hline
\end{tabular}

1299

1300

1301

1302

1303

1304

1305

1306

1307

1308 
1309 Figure 1

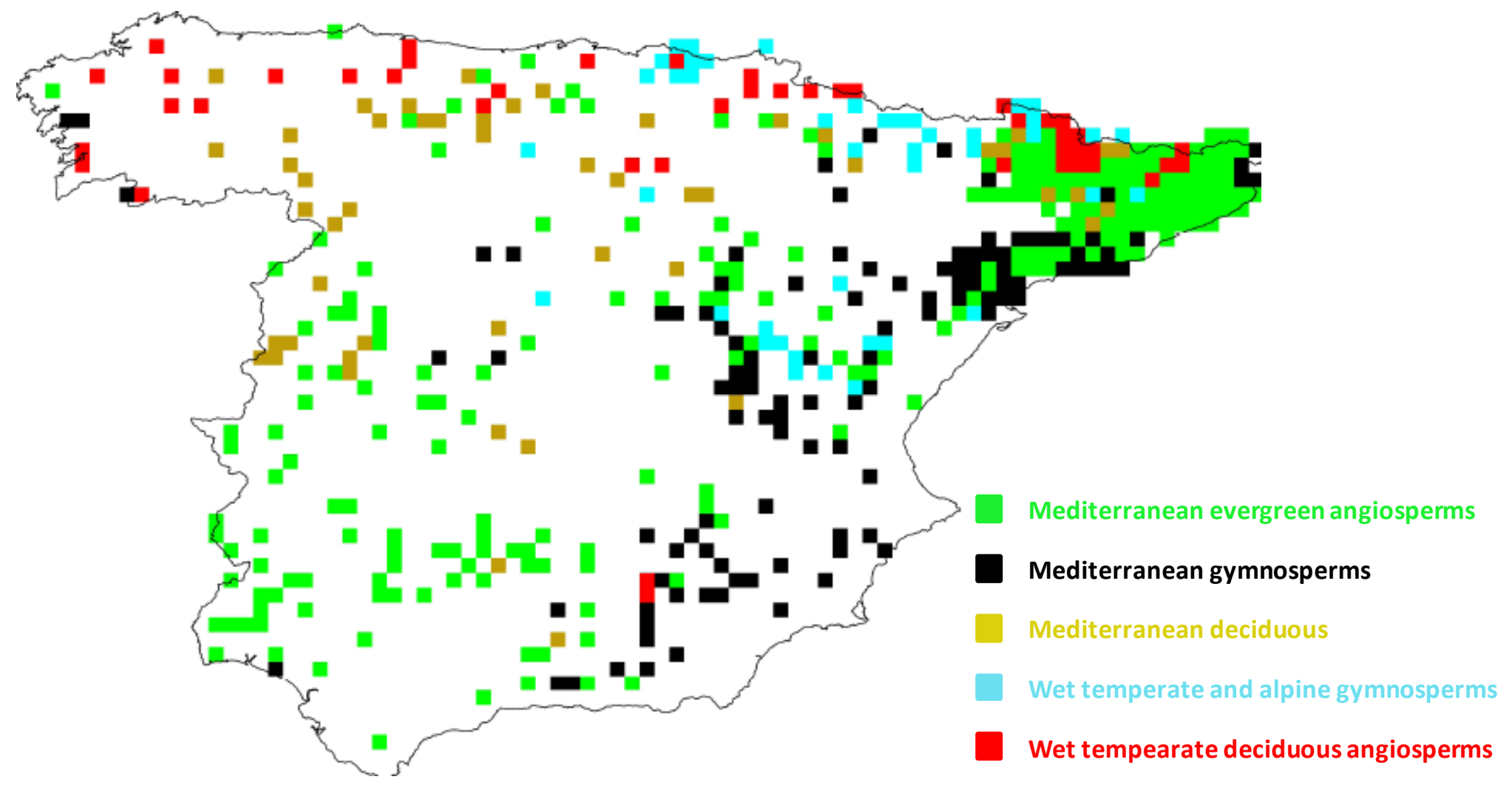


(A)

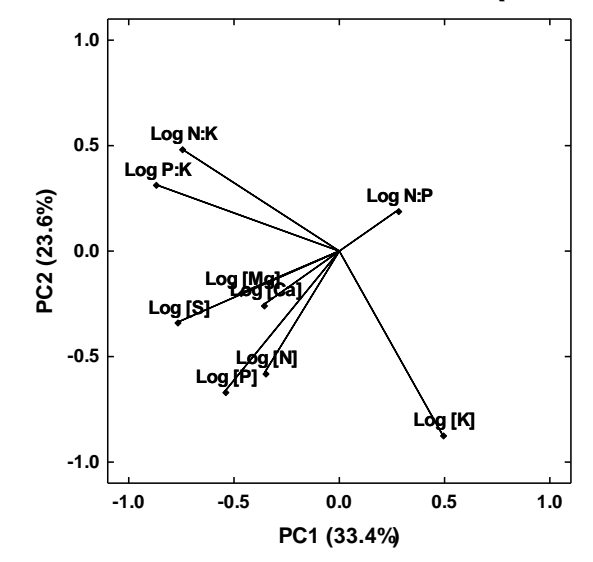

(B)
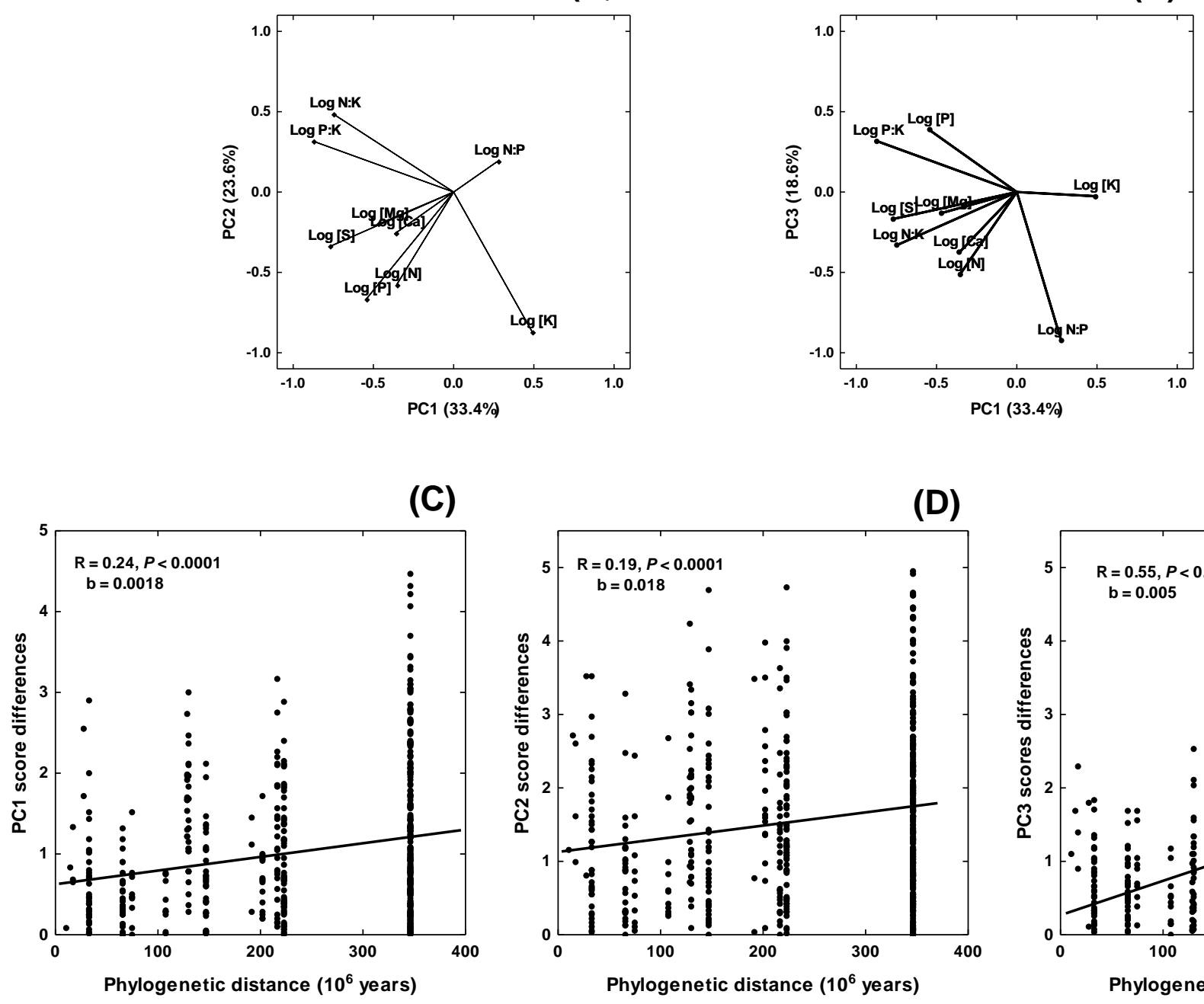

1311
(D)

(C)

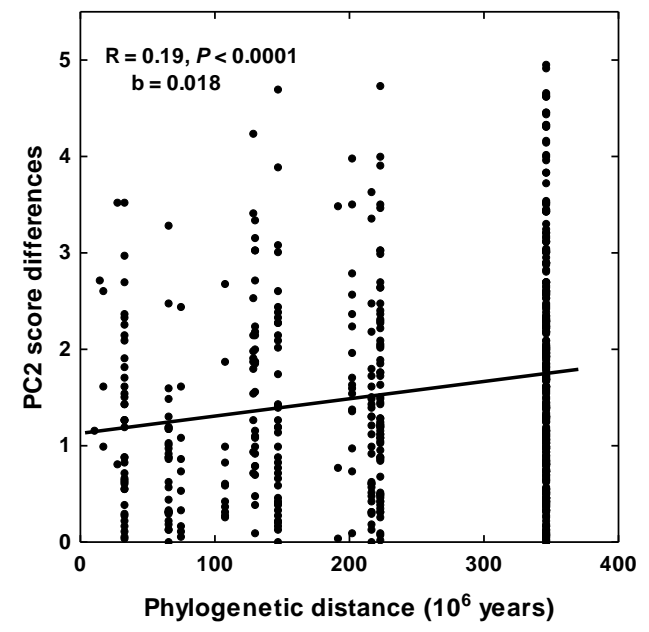

(E)

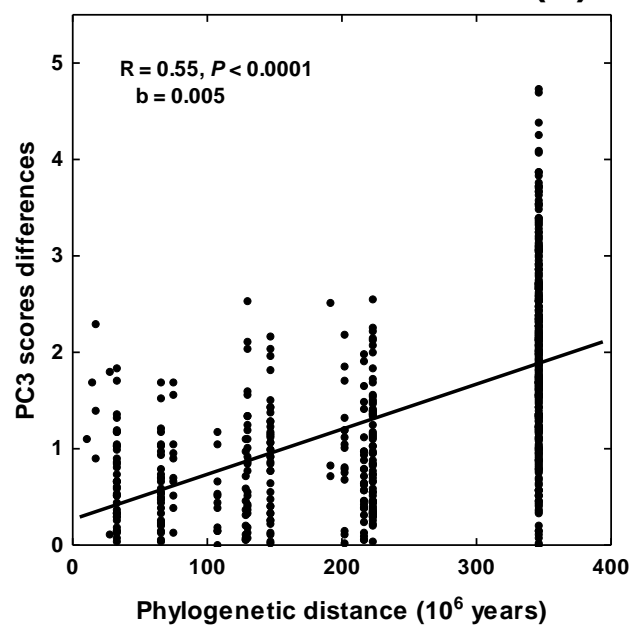

1312 Figure 2 


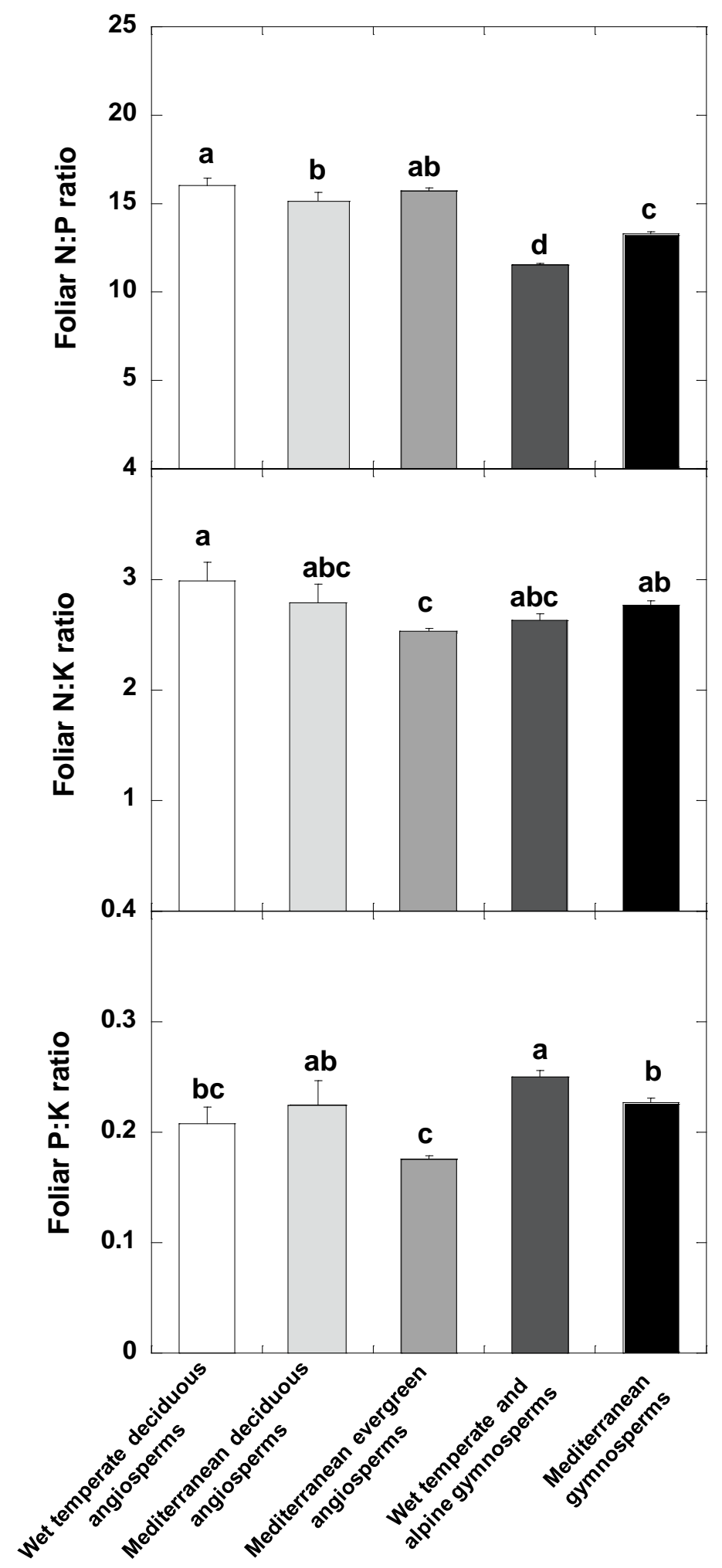

1313

1314 Figure 3 


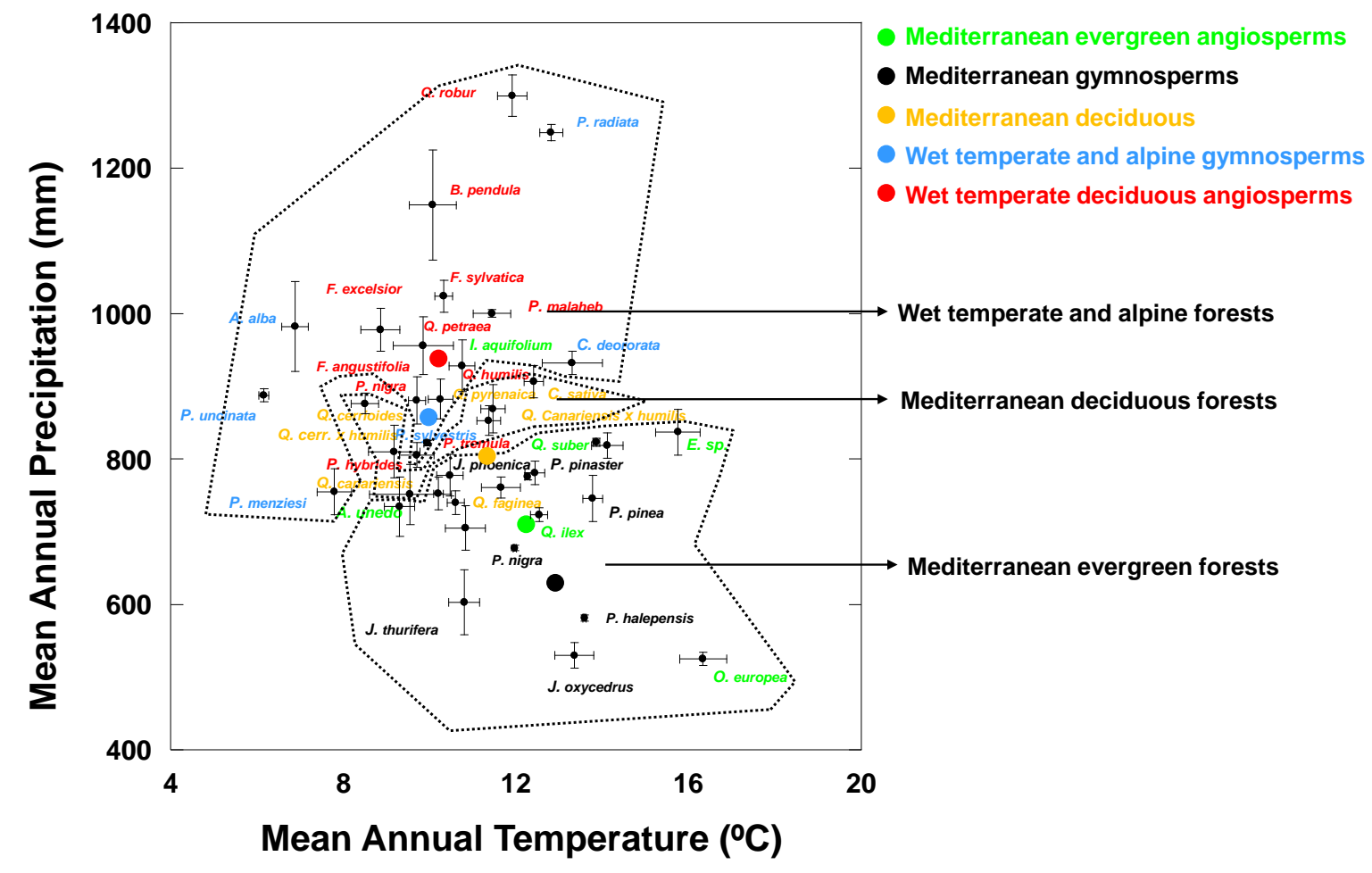

1315

1316

1317

1318

1319 Figure 4

1320

1321

1322

1323

1324

1325

1326 


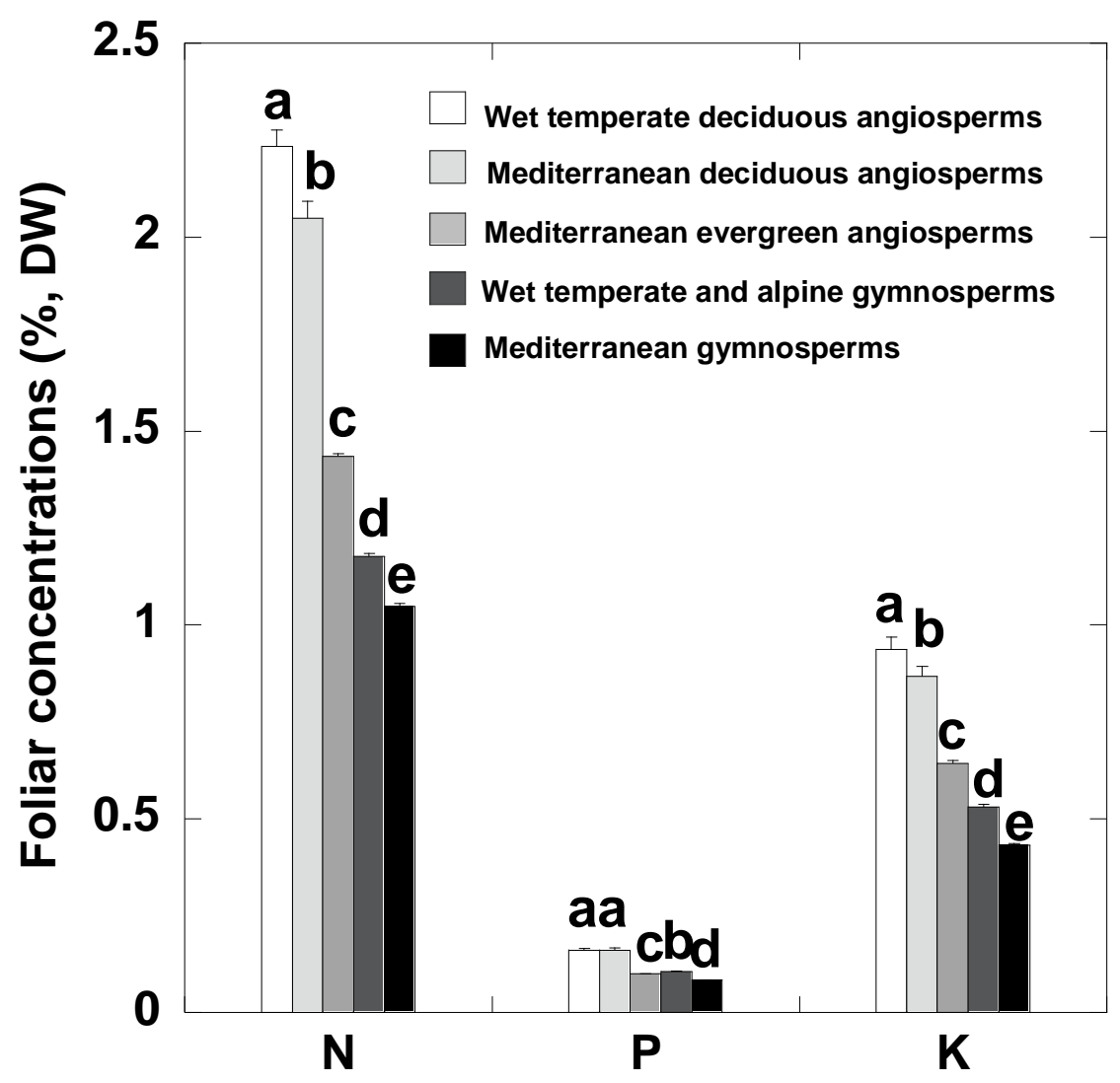

1327

1328

1329

1330

1331

1332

1333 Figure 5

1334

1335 


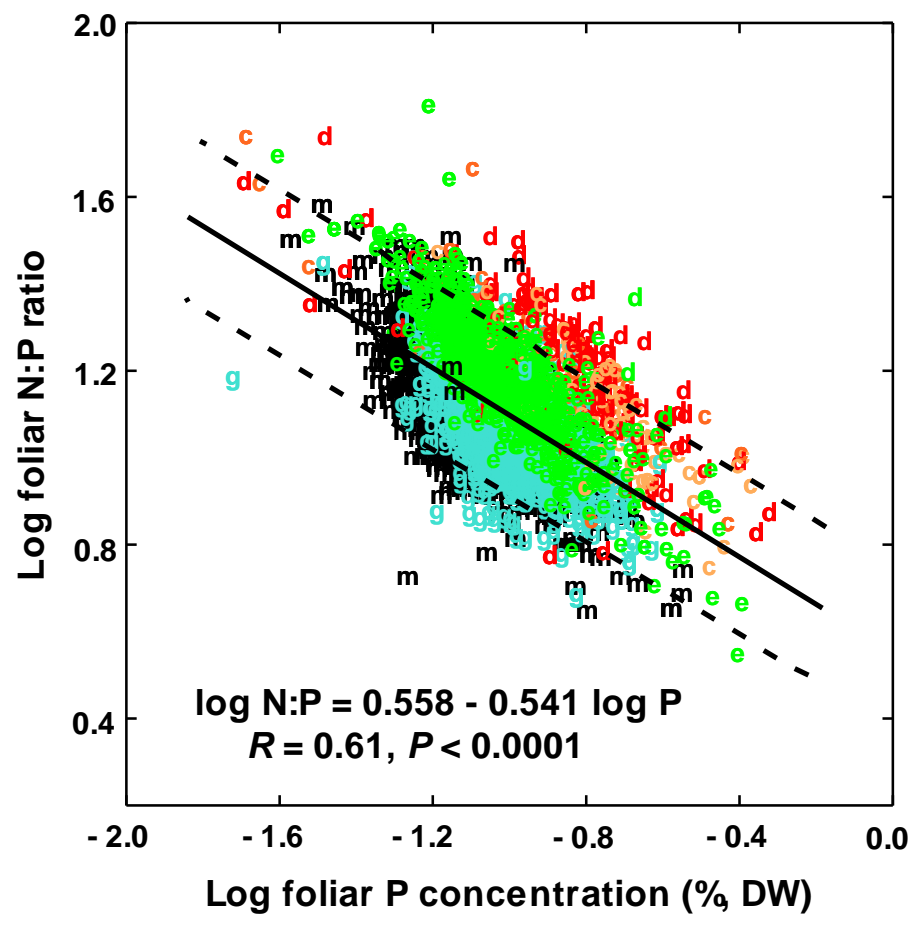

d Wet temperate deciduous angiosperms

c Mediterranean deciduous angiosperms

e Mediterranean evergreen angiosperms

g Wet temperate and boreal gymnosperms

m Mediterranean gymnosperms

1343 Figure 6

1344

1345

1346

1347

1348

1349 

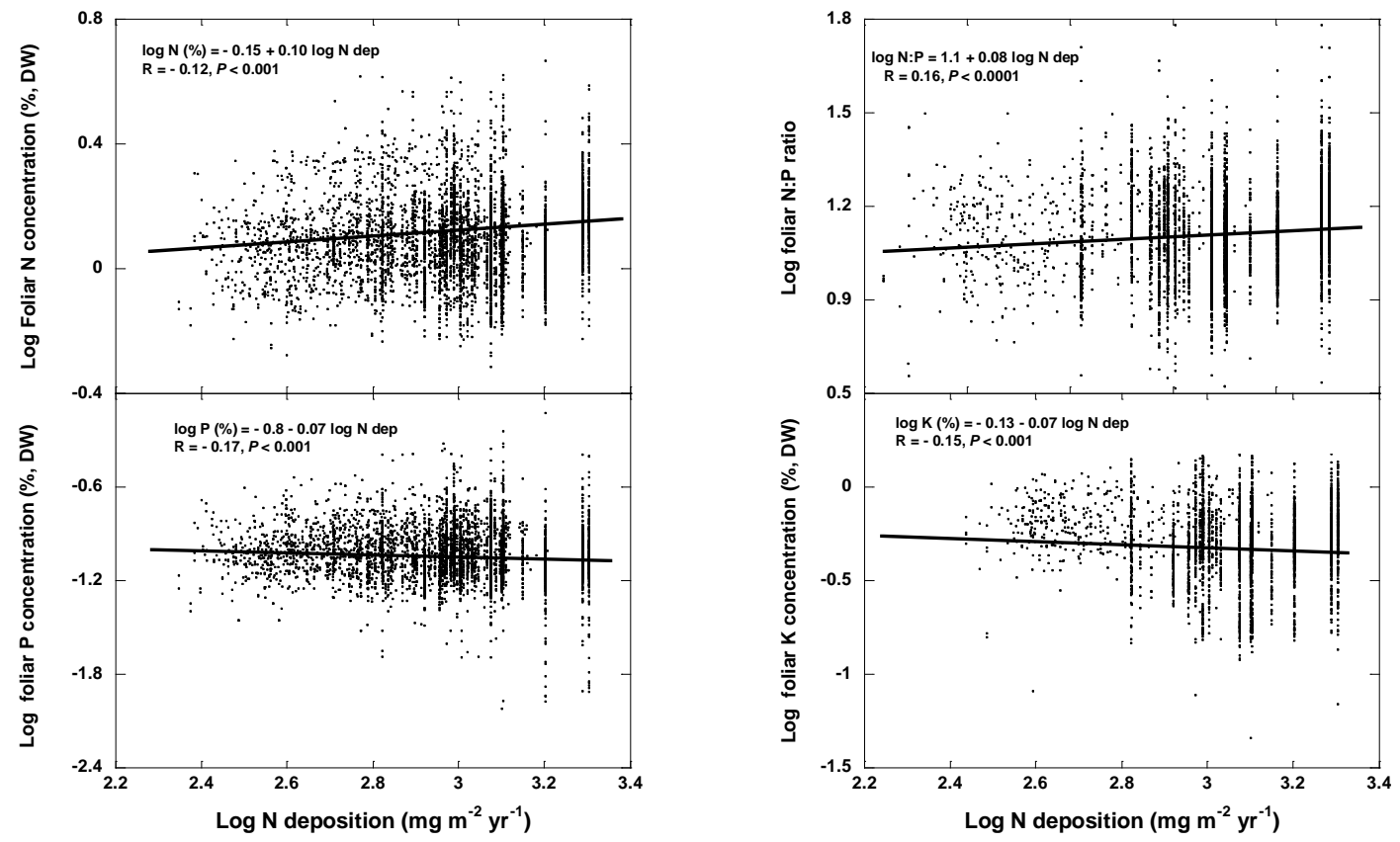


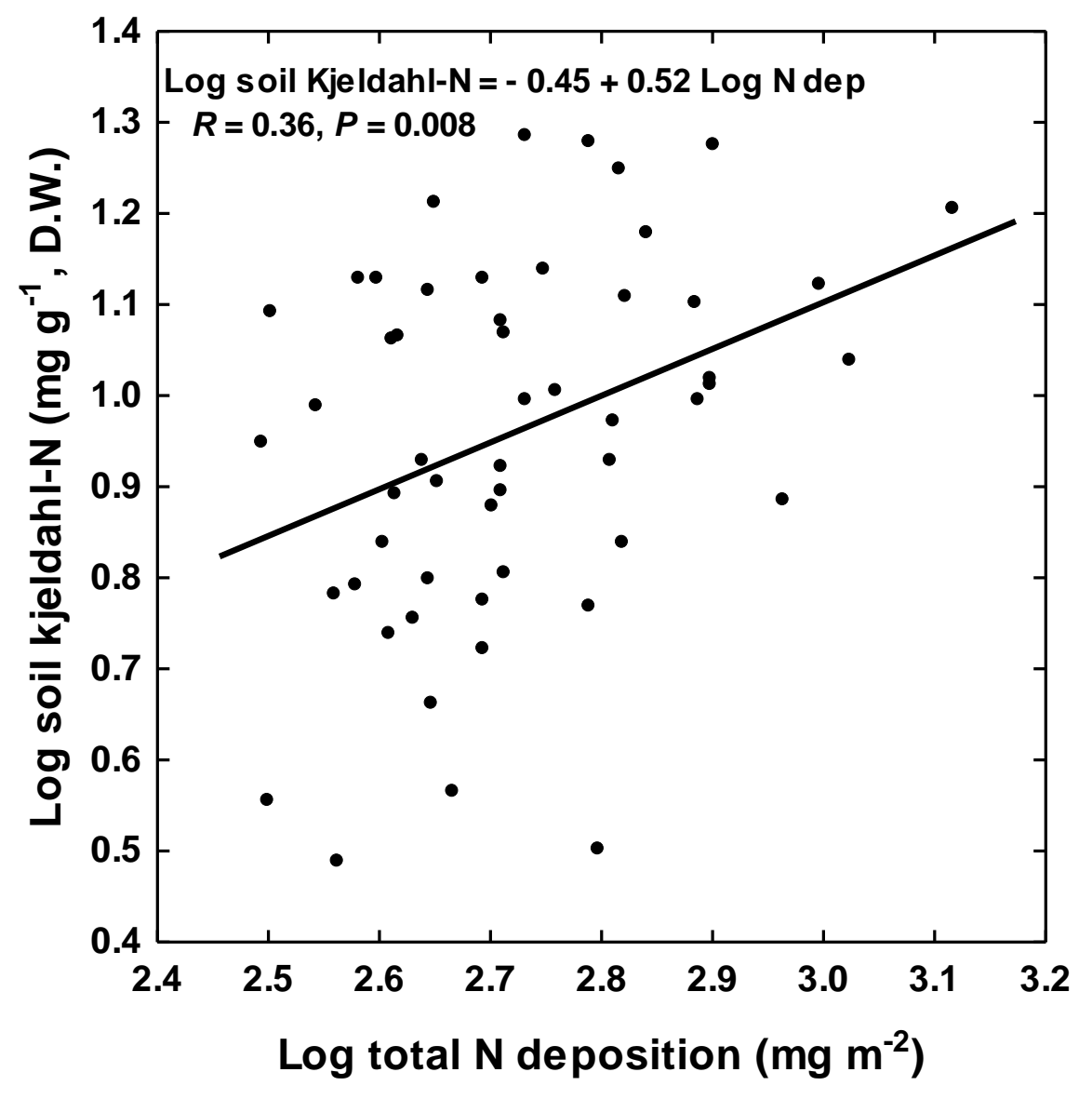

1352

1353 Figure 8 


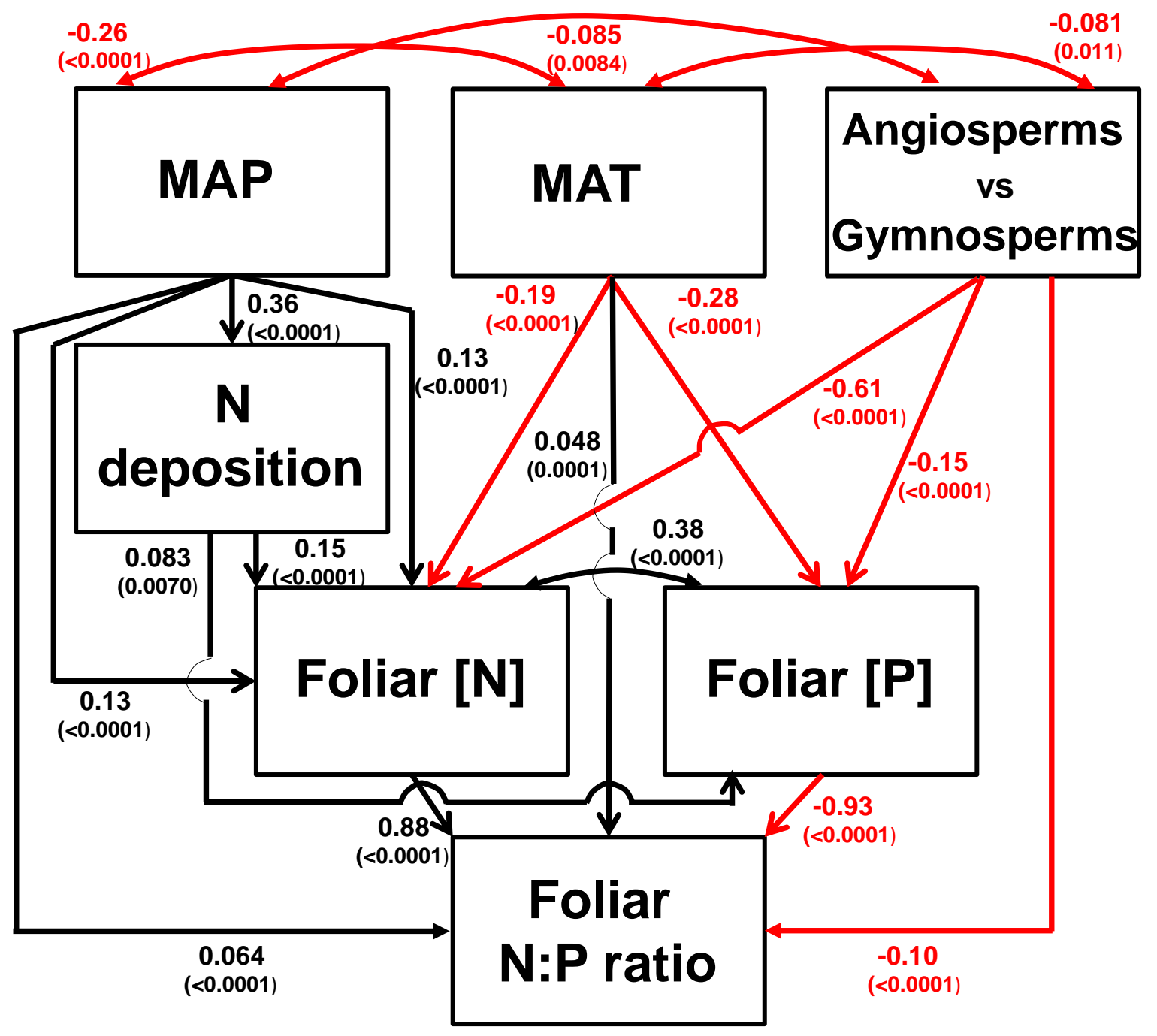

$\mathbf{R}^{2}$ for endogenous variables

$\mathrm{N}$ deposition Foliar [P] Foliar [N] foliar N:P ratio

0.13

0.10

0.47

0.88

Figure 9 

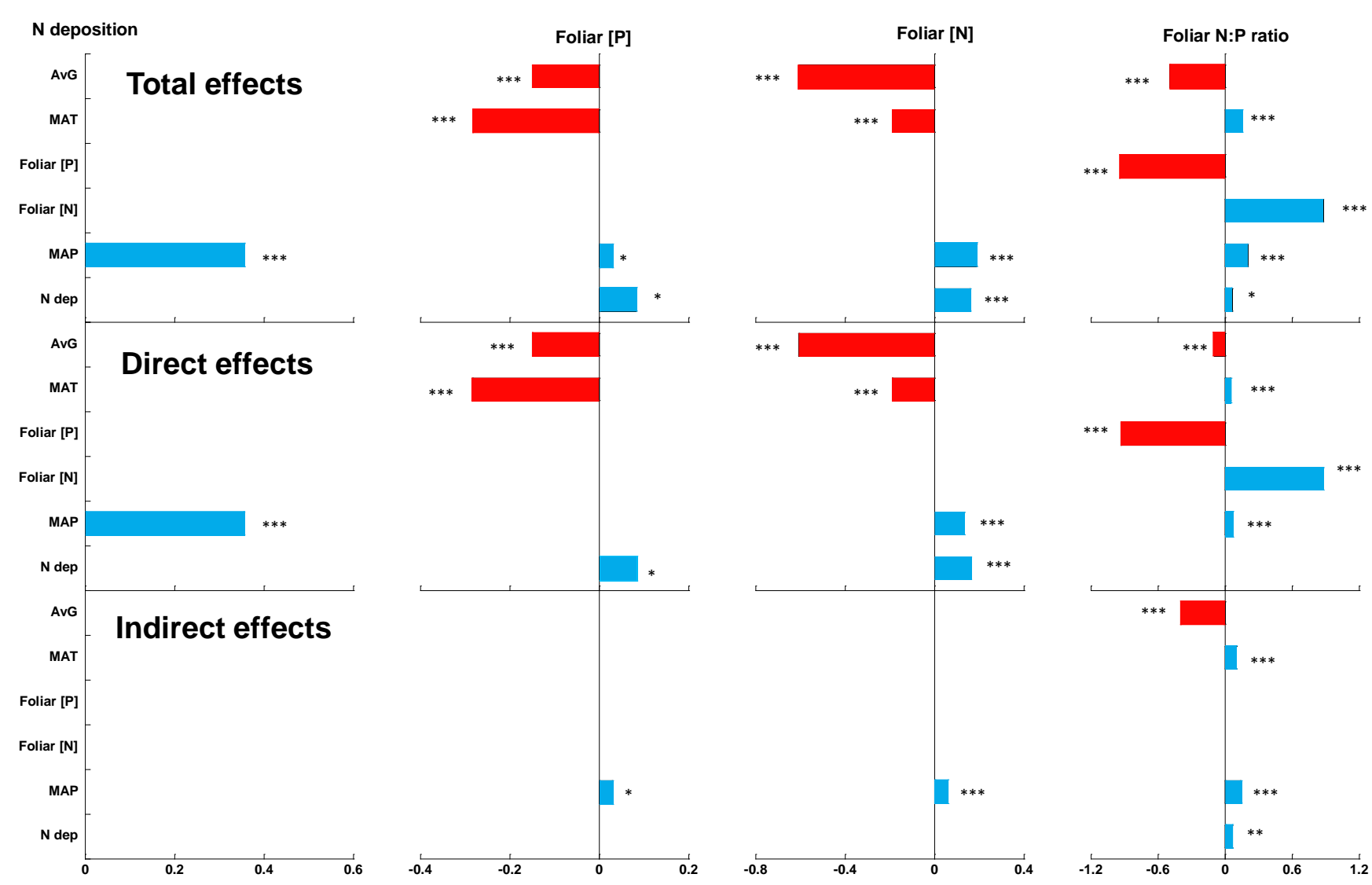

1359

1360 Figure 10 


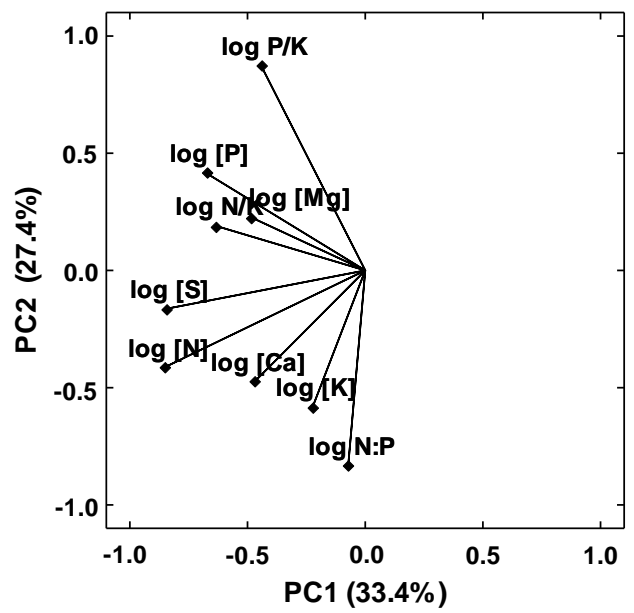

(A)
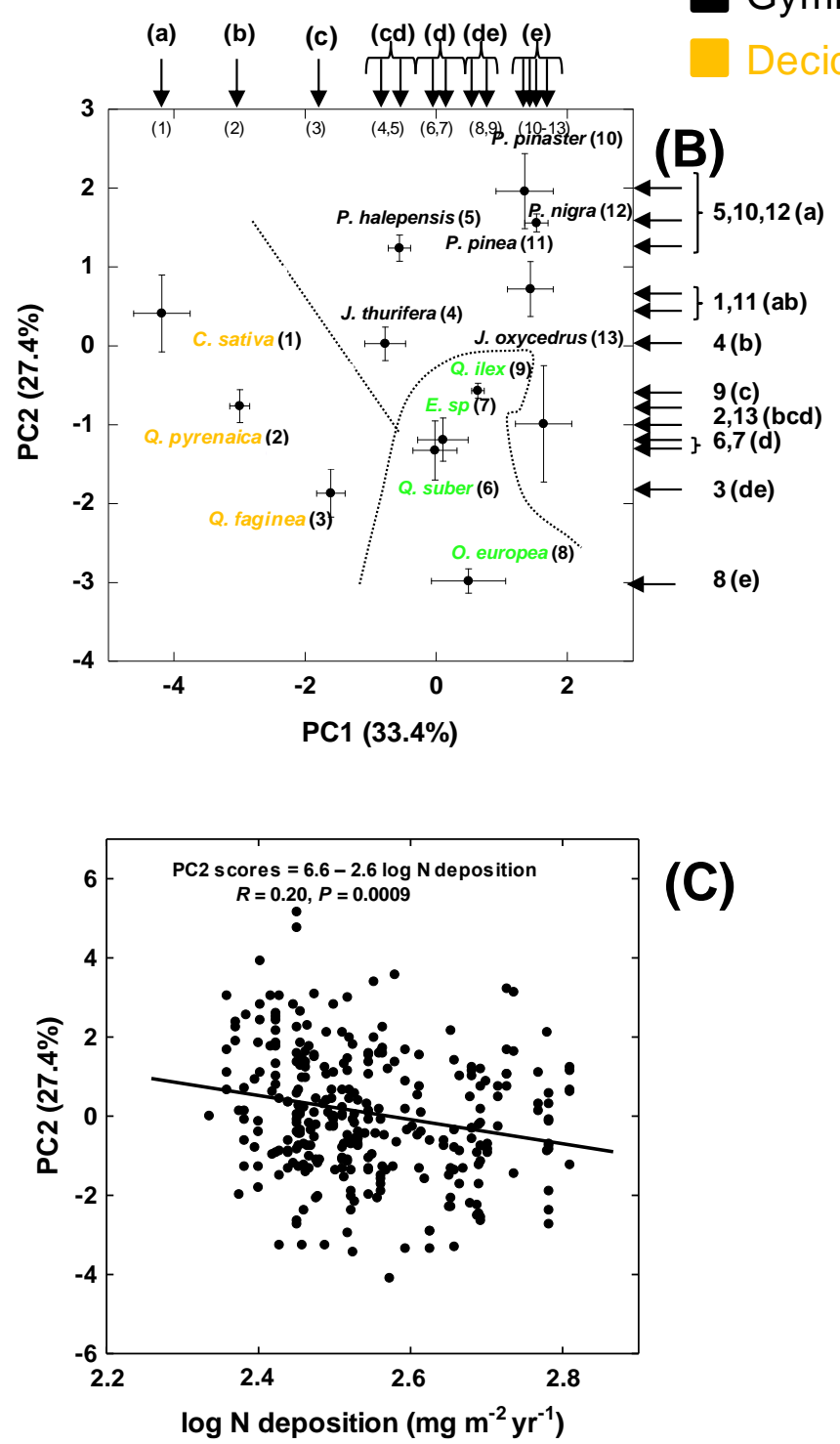

(C) 


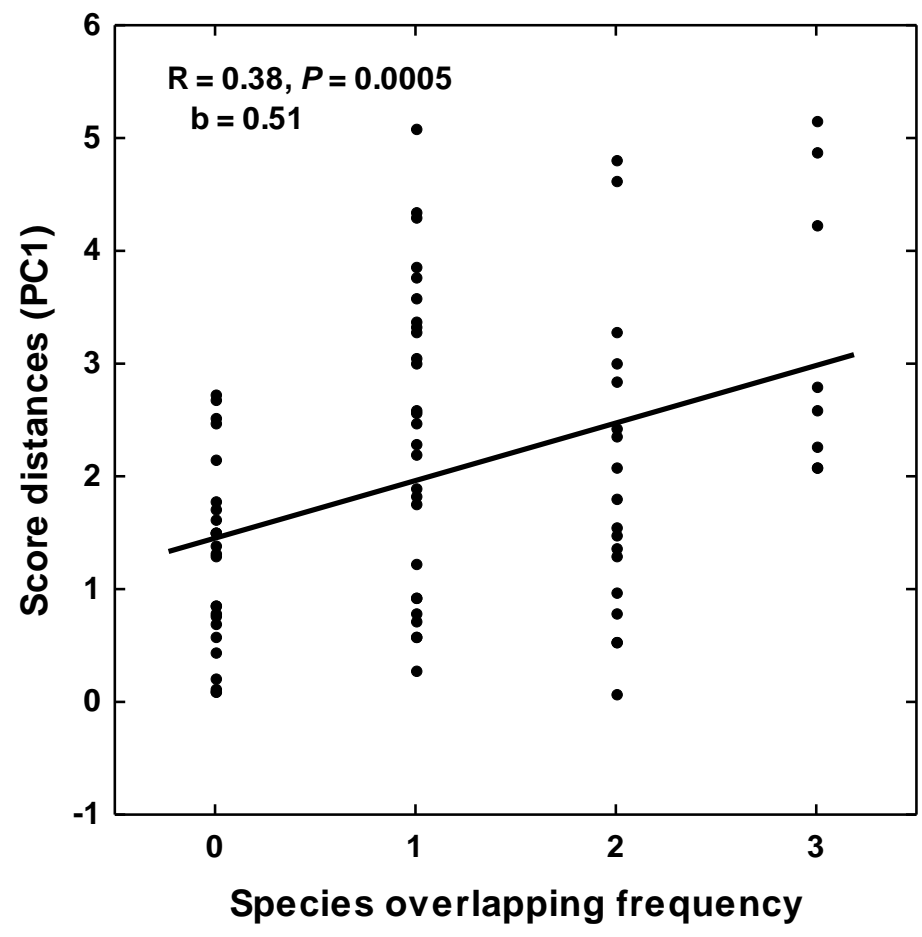

1363

1364

1365

1366 Figure 12

1367

1368

1369 